NBER WORKING PAPER SERIES

\title{
SIMULATING RUSSIA’S AND OTHER LARGE ECONOMIES' CHALLENGING AND INTERCONNECTED TRANSITIONS
}

\author{
Seth G. Benzell \\ Eugene Goryunov \\ Maria Kazakova \\ Laurence J. Kotlikoff \\ Guillermo LaGarda \\ Kristina Nesterova \\ Andrey Zubarev \\ Working Paper 21269 \\ http://www.nber.org/papers/w21269
NATIONAL BUREAU OF ECONOMIC RESEARCH
1050 Massachusetts Avenue
Cambridge, MA 02138
June 2015

Previously circulated as "Simulating Russia's Challenging Transition." We thank the Gaidar Institute and Boston University for research support. The views expressed herein are those of the authors and do not necessarily reflect the views of the National Bureau of Economic Research.

At least one co-author has disclosed a financial relationship of potential relevance for this research. Further information is available online at http://www.nber.org/papers/w21269.ack

NBER working papers are circulated for discussion and comment purposes. They have not been peerreviewed or been subject to the review by the NBER Board of Directors that accompanies official NBER publications.

(C) 2015 by Seth G. Benzell, Eugene Goryunov, Maria Kazakova, Laurence J. Kotlikoff, Guillermo LaGarda, Kristina Nesterova, and Andrey Zubarev. All rights reserved. Short sections of text, not to exceed two paragraphs, may be quoted without explicit permission provided that full credit, including (C) notice, is given to the source. 
Simulating Russia's and Other Large Economies' Challenging and Interconnected Transitions Seth G. Benzell, Eugene Goryunov, Maria Kazakova, Laurence J. Kotlikoff, Guillermo LaGarda, Kristina Nesterova, and Andrey Zubarev

NBER Working Paper No. 21269

June 2015П5 HMLHG6HSWP EHU प0

JEL No. F0,F20,H0,H2,H3,J20

\section{ABSTRACT}

This paper develops a large-scale, dynamic life-cycle model to simulate Russia's demographic and fiscal transition under favorable and unfavorable fossil-fuel price regimes. The model includes Russia, the U.S., China, India, the EU, and Japan+ (Japan plus Korea). The model predicts dramatic increases in tax rates in the U.S., EU, India, and Russia. Indeed, the increases are so large as to question their political feasibility let alone their actual collection given the potential for tax avoidance and tax evasion.

Seth G. Benzell

Boston University

Department of Economics

270 Bay State Road

Boston, MA 02215

sbenzell@bu.edu

Eugene Goryunov

The Gaidar Institute for Economic Policy

gorunov@iet.ru

Maria Kazakova

The Gaidar Institute for Economic Policy

and Russian Presidential Academy of

National Economy and Public Administration

kazakova@iet.ru

Laurence J. Kotlikoff

Department of Economics

Boston University

270 Bay State Road

Boston, MA 02215

and The Gaidar Institute for Economic Policy

and also NBER

kotlikoff@gmail.com
Guillermo LaGarda

Boston University

Department of Economics

270 Bay State Road

Boston, MA 02215

culagui@gmail.com

Kristina Nesterova

Russian Presidential Academy of

National Economy and Public Administration christina.nesterova@gmail.com

Andrey Zubarev

82 Vernadskogo prosp

117517, Moscow

Russian Federation

Zubarev@ranepa.ru 


\section{Introduction}

This paper develops a large-scale life-cycle model to simulate Russia's demographic and fiscal transition under favorable and unfavorable fossil fuel price regimes. The model includes six regions - Russia, the U.S., China, India, the EU, and Japan+ (Japan plus Korea).

Our precise quantitative and qualitative findings for each region are rather surprising and illustrate the power of highly detailed computable general equilibrium life-cycle models to inform predictions about future macroeconomic outcomes.

Our model builds on Fehr, Jokish, Kambhampati, and Kotlikoff (2014) by adding Russia and also including country-specific exhaustible fossil fuel endowments, albeit in a very simplified form. The model is calibrated to capture each region's current and projected future demographic conditions as well as its fiscal institutions. After 2058, we assume that births in each region stabilize. This assumption entails gradual changes in region-specific fertility rates and eventuates in stable populations after 90 years. These post-2058 paths to zero population growth produce a very different long-run age distribution in each region than now prevails.

In our baseline simulation, effective wage tax rates rise dramatically over the next few decades in the U.S., India and EU thanks to population aging. Interestingly, Japan+, which is already older than the other regions and which continues to age significantly through mid Century, experiences a less substantial increase in overall effective wage taxation. This reflects that region's relatively flat age-health expenditure profile, its assumed catch up productivity growth, its relatively low level of pension benefits, and the rapid projected growth in its consumption-tax base. The medium-term transition in China is relatively benign for many of the same reasons.

In 2084, when we assume fossil fuels are exhausted, tax rates increase globally. But the increase is largest for Russia. This reflects two factors. First, 17.1 percent of Russia's GDP arises from fossil fuel rents. Second, the Russian government collects 30.4 percent of its revenues from the sale of fossil fuels. In the U.S., in contrast, fossil fuels account for only 1.0 percent of GDP and only 1.1 percent of government receipts.

The baseline results for the U.S., EU, India, and Russia entail future tax rates that are sufficiently high so as to call into question their political feasibility. And while such high tax rates are economically viable according to the model (i.e., it converges), the model does not explicitly incorporate country-specific informal sectors that would permit workers to escape high rates of taxation. Inclusion of an informal sector, which is our near-term research goal, could well make projected expenditures paths in these regions infeasible. 
Our baseline is primarily calibrated based on IMF data for 2013. Other important data sources include the World Bank, OECD, and the ministries of finance of the countries concerned. But the year 2014 saw a dramatic decline in oil prices of roughly 50 percent. A permanent shock of this magnitude in fossil fuel output and state revenues puts Russia under even greater fiscal stress.

Russia is not without policy options. One is to gradually phase out its pay-as-you-go staterun pension system and its associated very high payroll tax and replace it with a personalized account system. ${ }^{1}$ This switch would constitute a reverse generational transfer policy - redistributing from current middle-age Russians to young and future Russians. It would boost the welfare of those living in the future by significantly lowering their average and marginal tax rates.

A second option is to eliminate Russia's corporate income tax and make up lost revenue by raising consumption and income taxes. This would induce a major inflow of capital to Russia, which would raise Russian wages and GDP. ${ }^{2}$

A third option is to raise Russia's fertility rate significantly (we consider a 25 percent increase) via a means that we leave unspecified. This would increase the tax base in the medium term, helping to sustain the country's expensive public outlays and transfer programs.

According to our model, raising Russia's fertility rate has a pronounced impact on the country's future GDP. This impact goes beyond that associated with pension or corporate-tax reform. The lesson here is that the size of the Russian work force, not improved work incentives facing Russian workers (via lower marginal tax rates or higher pre-tax wages), is of paramount importance in determining Russia's production of goods and services.

These findings are both reasonable and expected. The model's realistically calibrated preferences over goods and leisure entail largely offsetting income and substitution effects when it comes to workers increasing their labor supply in response to a higher net wage. But the fact that neither pension nor corporate tax reform generate far greater levels of GDP doesn't undermine their value in improving other economic indicators. Pension reform is extremely useful when it comes to lowering long-term effective wage-tax rates. And corporate tax reform is extremely effective in raising short-, medium-, and long-run levels of wages.

Each of the three Russian policies - pension reform, corporate-tax reform, and increased fertility - is purely hypothetical. There is no reason to believe that the Russian government has any plans whatsoever to enact any of these policies.

\footnotetext{
${ }^{1}$ See, for example, www.thesocialsecuritypurpleplan.org

${ }^{2}$ Fehr, et. al. (2013) study this policy for the U.S.
} 
But these or related policies could make a major positive impact on Russia's transition. They are, therefore, worth considering as a potential future guide to policy making. In combination the three policies can more than offset any damage done by an ongoing collapse in fossil-fuel revenues.

This said, phasing out its pension system, cutting corporate income taxes, or raising fertility rates may not be politically or, in the case of fertility, socially feasible. Moreover, given that Russia currently has a very low debt-to-GDP ratio, Russian politicians may opt, at least in the short term, to borrow rather than raise tax rates. To investigate the consequences of such borrowing we also simulate a policy of keeping tax rates fixed for the next 10 years. As we show, postponing Russia's fiscal fallout in this manner only makes its eventual fiscal adjustment larger and more painful.

The next section reviews the literature on multi-country, dynamic, life-cycle simulation models. Subsequent sections present our model, discuss its calibration, present baseline results, consider a permanent 50 percent reduction in fossil-fuel rents, consider policy alternatives in the context of low fossil-fuel prices, examine the costs of maintaining the status quo, and conclude.

\section{Literature Review}

The development of computable general equilibrium dynamic life-cycle simulation models dates at least to Tobin's (1967) steady-state analysis of the role of life-cycle saving in aggregate wealth accumulation. A half century later, CGE models with overlapping generations have become a standard tool for quantifying the economic effects of fiscal reforms and demographic changes. ${ }^{3}$

Were all generations altruistically linked, as in Barro (1974) and the vast RBC literature, they would effectively operate as one economic unit in deciding how much to work, save, and consume. In that case there would be no need to know which generations held particular amounts of assets or accounted for different shares of labor income. Nor would we be concerned with generational policy - policies that redistribute across generations.

But the evidence against operational intergenerational altruism seems overwhelming whether one looks at micro studies of consumption (e.g., Altonji, Hayashi, and Kotlikoff, 1992, 1997 and Hayashi, Altonji and Kotlikoff, 1996), cohort studies of consumption (e.g., Abel and Kotlikoff, 1994), or studies of changes in the relative consumption of different cohorts (e.g.,

\footnotetext{
${ }^{3}$ This section draws heavily on Fehr, et. al. (2013).
} 
Gokhale, Kotikoff, and Sablehaus, 1993 and Lee, 2014).

In late 1979 Auerbach and Kotlikoff began developing a method for solving transition paths of large scale OLG models inhabited by agents who form rational expectations. Their first working paper, Auerbach and Kotlikoff (1981), assumed inelastic labor supply and very simple demographics. But it showed the potential for exploring a range of fiscal and demographic questions. The authors quickly added variable labor supply and demographic change. Their early work is summarized in Auerbach and Kotlikoff (1987).

Auerbach, et. al. (1989) is the first multi-country ancestor of this model. Kotlikoff, Smetters, and Walliser (2007) added age-specific and time-varying fertility and mortality, multiple earnings groups, life-span uncertainty, and bequests arising strictly from incomplete annuitization. Fehr, Jokisch, and Kotlikoff (2008) added multiple goods to the multi-country OLG framework, some traded and some not. Their paper also developed an iterative numerical method to solve for the time-varying pattern of specialization in the production of traded goods.

Other early work simulating life-cycle models includes Kotlikoff's (1979) steady-state model of unfunded Social Security, Summers (1979) myopic expectations model of dynamic transitions, and Seidman's (1986) study of the effects of eliminating Social Security. Somewhat more recent papers considered the importance of land, earnings uncertainty, political economy considerations, liquidity constraints and different options for funding Social Security. These studies include Hubbard and Judd (1987), Imrohoroglu, et. al. (1995, 1999), Kotlikoff (1996), Huang et al. (1997), Huggett and Ventura (1999), Cooley and Soares (1999a,b), De Nardi, et. al. (1999), Kotlikoff, et. al. (1998a,b,1999,2002), Raffelhuschen (1989, 1993), Bohn (2001), Smetters and Walliser (2004), and Diamond and Zodrow (2012).

Broer and Westerhout (1997) include age-specific mortality rates and uncertain life span so that individual consumption and saving decisions are influenced by aging. While in their model assets are completely annuitized, Kato (2002) and others assume that people leave unintended bequests. In contrast, De Nardi, et. al. (1999) consider a life-long bequest motive and assume inheritances to be received throughout the life cycle. Fehr (2000) and Beetsma, et. al. (2003) distinguish different productivity profiles within cohorts to account for intra-generational distribution effects of social security reforms. Nishiyama and Smetters (2005) assume heterogeneous agents who face idiosyncratic wage shocks. Hasanhodzic and Kotlikoff (2013) calibrate and simulate 80-, 40-, and 20-period OLG life-cycle models with aggregate productivity shocks in order to assess the size of generational risk and the ability of the government to mitigate such risk. Hasanhodzic and Kotlikoff (2014) use their framework to value government promises in the context of incomplete markets. 
Many of these models focus on demographic changes in a single economy modeled either as closed or small and open. However, the different timing and extent of national aging processes can be expected to impact worldwide factor prices and to trigger major international capital flows. Not surprisingly, multi-region CGE models have been developed that analyze the demographic transition in an international context. Examples are Borsch-Supan, et. al. (2006) and Ingenue (2007). These studies find that aging leads to a crowding in of capital, which raises wages and decreases the return to capital.

The multi-region models of Fehr, Jokisch, and Kotlikoff (2004, 2005, 2008b) draw a different conclusion; i.e., they show that two forces lead to at least some shortage of capital (an increase in the effective supply of labor relative to capital) over time. First, productivity growth can expand effective labor supplies even if the number of new workers coming into the workforce is declining. Second, rising taxes needed to pay older cohorts their government pensions and health care benefits limit the saving of younger cohorts.

Brooks (2003) is an early CGE model with developing as well as developed countries. His framework features eight regions - three developed (EU, Japan, North America) and four developing regions (Eastern Europe, Africa, Latin America, China). He finds that the developed regions export capital to the developing regions as long as the baby boom generations are still in the work force. After 2030 when these generations retire and start decumulating their assets, capital will be repatriated to the developed countries.

However, Brooks (2003) assumes that the technology levels in developing countries like China remain unchanged. Other studies assume ongoing closure of the gap in per capita incomes between the developed and developing world. Saarenheimo (2005), for example, presents a five-region model that has China and India reaching 40 percent of the European labor productivity by 2050 .

Aglietta, et. al. (2007) consider different rates of Asian catch up. They find that China will improve its current account dramatically between 2030 and 2050 if it catches up to total factor productivity in North America by 2100. In their model, North America is the largest supplier of capital in the medium and long run. Finally, Fehr, et. al. (2007) show the major importance of the future saving behavior of the Chinese population. If China maintains its very high saving rate it could become the developed world's major medium-term supplier of capital.

These studies as well as Fehr, Jokisch, Kallweit, Kindermann, and Kotlikoff (2013) give important insights into how demographic changes might affect international capital movements. What they miss is the fact that the demographic developments together with the dramatic economic growth of Asian regions will also have a major impact on production structures and 
international commodity trade. Aglietta, et. al. (2007) and Ingenue (2007) account for international commodity trade but omit other key factors, such as different final consumption goods.

Fehr, Jokisch, and Kotlikoff $(2010,2013)$ fill in some of these gaps. Their papers analyze the impact of globalization on the world's demographic/fiscal transition path, particularly the course of wage inequality. Their dynamic life-cycle model features six goods and five regions. It predicts a substantial increase of the ratio of high- to low-skilled wages over the century. The major source of this increase comes from Chinese and Indian productivity catch up that produces a significant growth in the relative global supply of unskilled labor.

\section{Model}

In presenting our model, we begin with demographics and then discuss household preferences. We then turn to the model's supply side including our simple formulation of the energy sector. Next we specify the model's fiscal policy. Finally, we explain the model's solution algorithm.

\subsection{Demographics}

Agents in each region live at most to age 90. Consequently, there are 91 generations with surviving members at any point in time. The life cycle of a representative agent is depicted in figure 1. Between ages 0 and 20 agents are non-working children supported by their parents. At age 21 agents enter the labor force and accumulate assets. Between ages 23 and 45 agents give birth, annually, to fractions of children.

Why fractions of children? The answer is to generate realistic distribution of births by age and, thereby, produce realistic distributions of population by age. This approach, which dates to Kotlikoff, Smetters and Walliser (2007), precludes having to incorporate marriage in the model with different couples producing different numbers (including zero) of children at specific child-bearing ages.

An agent's first-born children (those born when the agent is 23) leave home 21 years later when the agent is age 44 and the last-born (those born when the agent is 45) leave when the agent is age 66 .

Agents die at an increasing rate between ages 68 and 90, with the probability of death at age 90 set to 1 . The assumption that no one dies prior to age 68 simplifies our modeling of bequests. It ensures that children always outlive their parents. To see this, note that if a parent reaches 
age 90 , her oldest children, born when the parent was 23, will be 67. For India, where infant mortality is strikingly high, we also incorporate a small rate of infant mortality. This rate is .0093 in 2013 and it declines linearly to .0003 in 2058. After that date it remains constant. Infant mortality in the other regions is neglible and its inclusion would not materially alter our calibration.

Agents accrue no utility from leaving bequests. Hence there are no intentional bequests. Instead, bequests arise due to the model's agents not being fully annuitized. I.e., they die with assets on hand that they intend to spend through the rest of their potential lives.

Figure 1: The individual life-cycle

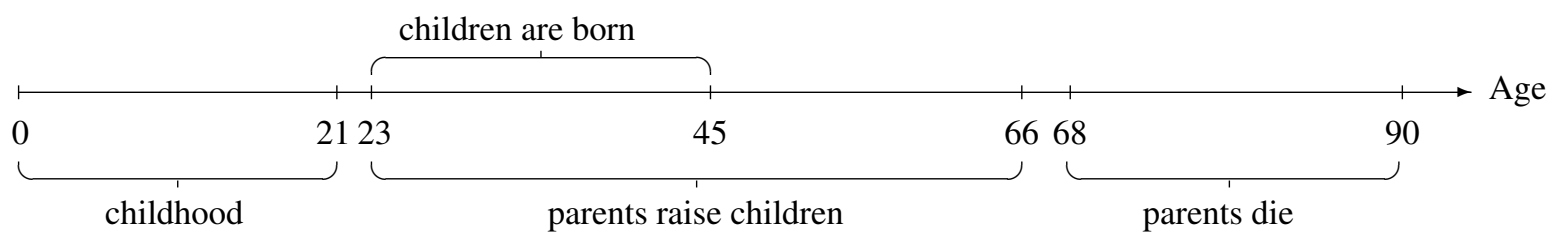

The model also includes annual age- and skill-specific immigration. In each year new immigrants in each skill and age group arrive with the same number and age distribution of children and the same level of assets as natives of the identical skill and age. Once they join a native cohort, they experience the same future age-specific fertility and mortality rates as native-born cohort members.

\subsection{The household sector}

The model's preference structure is represented by a time-separable, nested, CES utility function. Remaining lifetime utility $U(a, t, k)$ of an agent age $a$ at time $t$ belonging to skill-class $k$ takes the form

$$
U(a, t, k)=V(a, t, k)+H(a, t, k)
$$

where $V(a, t, k)$ records the agent's utility from her own consumption and leisure and $H(a, t, k)$ denotes the agent's utility from the consumption of her children. The two sub-utility functions are defined by

$$
\begin{aligned}
V(a, t, k) & =\frac{1}{1-\frac{1}{\gamma}} \sum_{i=a}^{90}\left(\frac{1}{1+\delta}\right)^{i-a} P(a, i, t)\left[c(i, t+i, k)^{1-\frac{1}{\rho}}+\varepsilon \ell(i, t+i, k)^{1-\frac{1}{\rho}}\right]^{\frac{1-\frac{1}{\gamma}}{1-\frac{1}{\gamma}}(2)} \\
H(a, t, k) & =\frac{1}{1-\frac{1}{\gamma}} \sum_{i=a}^{90}\left(\frac{1}{1+\delta}\right)^{a-i} K(a, i, t, k) c_{K}(a, i, t, k)^{1-\frac{1}{\gamma}}
\end{aligned}
$$


where $P(a, i, t)$ is the probability that an agent who is age $a$ at time $t$ will survive to age $i$, $c(a, i, t, k)$ is the age- $i$ consumption of an agent in skill class $k$ who is age $a$ at time $t, l(a, i, t, k)$ is the age- $i$ leisure of an agent in skill class $k$ who is age $a$ at time $t, K(a, i, t, k)$ is the number of children of an agent age $a$ at time $t$ in skill class $k$ when the agent is age $i$, and $c_{K}(a, i, t, k)$ is consumption per-child at time $t$ of an agent age $a$ in skill class $k$ when the agent is age $i$.

The parameters $\delta, \rho, \varepsilon$ and $\gamma$ represent the rate of time preference, the intratemporal elasticity of substitution between consumption and leisure, the leisure preference parameter, and the intertemporal elasticity of substitution between consumption and leisure, respectively.

The probability of an agent age $a$ at time $t$ surviving to age $i$ is

$$
P(a, i, t)=\prod_{z=a}^{i}[1-d(a, z, t)]
$$

where $d(a, z, t)$ is the agent's probability of dying at age $z$ conditional on surviving to that age.

The assets $\mathrm{A}(a, t, k)$ of a skill- $k$ agent who is age $a$ at time $t$ evolve according to

$$
\begin{array}{r}
\mathrm{A}(a+1, t+1, k)=[\mathrm{A}(a, t, k)+I(a, t, k)](1+r(t))+w(a, t, k)[h(a, t)-\ell(a, t, k)] \\
-T(a, t, k)-\left[c(a, t, k)+K(a, t, k) c_{K}(a, t, k)\right],
\end{array}
$$

where $r(t)$ is the pre-tax return, $I(a, t, k)$ are inheritances received in year $t, h(a, t, k)$ is the endowment of time, $T(a, t, k)$ is net taxes (taxes paid net of pension, disability, and other transfer payments received). $T(a, t, k)$ includes all taxes, including taxes on asset income, taxes on labor income, and consumption taxes.

To calculate $I(a, t, k)$ we sum together all bequests within a skill class and distribute them by age. Private assets of all agents who died are aggregated and then distributed according to an endogenous age-dependent distribution scheme $\Gamma(l, t)$ to all agents aged between 23 and 67. These bounds are the maximum age of death minus the minimum age of fertility, and the minimum age of death minus the maximum age of fertility. To be precise, the inheritance of agents age $l$ in year $t$ is given by:

$$
I(l, t, k)=\Gamma(l, t) \frac{\bar{A}(t, k)}{N(l, t, k)} \quad \text { where } \quad \sum_{l=23}^{67} \Gamma(l, t)=1 .
$$

The numerator in this ratio measures the aggregate assets of skill-class $k$ agents who die in year $t$. A share $\Gamma(l, t)$ of these bequests is dedicated to inheritants aged $l$ of the same skill class. This 
share is split equally among all agents of the same age and skill group. $\Gamma(l, t)$ is the distribution of the ages of children of individuals dying in that year.

As in Altig, et. al. (2001) and Kotlikoff, Smetters and Walliser (2007), we model technical progress as permitting successive generations to use time more effectively whether in working or enjoying leisure. We implement this assumption by having the time endowment of successive generations in each region grow at the common rate $\lambda$. Denote $h(a, i)$ as the time endowment of an agent age $a$ at time $i$, then

$$
h(a, i)=(1+\lambda) h(a, i-1)
$$

This treatment of technical change ensures eventual convergence of the economy to a longrun steady state. Other formulations of technical change, such as making it labor-augmenting, preclude a steady state given the model's preferences. This would preclude using our iterative method for determining the model's equilibrium transition path, which requires the terminal conditions provided by the economy's long-run steady state. ${ }^{4}$

Gross labor income of an agent in year $i$ is derived as the product of her labor supply and wage rate. The latter is the product of the skill-specific wage rate $w(k, i)$ in year $i$ and ageand year-specific productivity per time-unit $E(a, i)$. Energy endowment income is denoted by $x(l, t, k)$.

Net taxes, $T(l, t, k)$, include consumption, capital income, and progressive income taxes as well as social security contributions net of pension, disability, and health benefits received in the form of transfer payments. Given the assumed ceiling on payroll tax contributions, payroll tax rates, both average and marginal, differ across agents. Each agent's pension benefits depend on her pre-retirement earnings history. In contrast, health care and disability benefits are provided on a per capita basis with an adjustment for relative benefits by age. Finally, households receive lump-sum rebates of part of the corporate tax payments made on their behalf. These rebates are needed to ensure reasonable average corporate tax rates, while permitting, for most regions, the use of much higher marginal corporate tax rates.

Given price indices $p(a, i)$, interest rates $r(i)$, and wages $w(k, i)$, agents maximize utility (1) subject to the intertemporal budget constraint (5) and the constraint that leisure in each period not exceed their time endowment (i.e. $\ell(l, t, k) \leq h(l, t)$ ). They do this by choosing their leisure and consumption demands, i.e., $\ell(l, t, k), c(a, i, k)$ and $c_{K}(a, i, k)$.

\footnotetext{
${ }^{4}$ Note that assuming a higher rate of technical progress is isomorphic to assuming the economy has more agents with the same endowment of time. Clearly, adding agents to the model doesn't limit its ability to reach a steady state.
} 
Given individual consumption and leisure, agents' asset levels are derived from (5). Aggregate values of assets, private consumption goods, and labor supply obey

$$
\begin{aligned}
A(t+1) & =\sum_{k=1}^{2} \sum_{a=21}^{90} \underbrace{\mathrm{a}(a+1, t+1, k) N(a, t, k)}_{\bar{A}(a+1, t+1, k)}, \\
C(t) & =\sum_{k=1}^{2} \sum_{a=21}^{90}\left[c(a, t, k)+K I D(a, t, k) c_{K}(a, t, k)\right] N(a, t, k), \\
L^{s}(k, t) & =\sum_{a=21}^{90} E(a, t)[h(a, t)-\ell(a, t, k)] N(a, t, k) .
\end{aligned}
$$

Since households die at the beginning of each period, we aggregate across all agents alive at the end of the prior period to compute $\bar{A}(a+1, t+1, k)$, which is used in the calculation of bequests (see (6)). Total assets of agents alive at the end of period $t+1$ can be written as

$$
\mathcal{A}(t+1)=\sum_{k=1}^{2} \sum_{a=21}^{90} \mathrm{a}(a, t+1, k) N(a, t+1, k)
$$

which includes the assets of period $t+1$ immigrants.

\subsection{Adding Energy to the Model}

The current model adds an energy sector to Fehr, et. al. (2013), albeit one formulated in the simplest possible manner. Specifically, we model the endowment of fossil fuels in each country as generating an annual flow of the model's single output good. This flow is net of extraction costs. All regions exhaust their energy resources at the same time.

The model specifies the size of the global energy flow, its division across regions, and the share of each region's flow owned by the government. The government's share of its region's flow of output from the energy sector is treated as a receipt. The flow of energy in each country is constant through time up to the point of exhaustion. And since the global economy grows, GDP originating in the fossil-fuel sector declines each year through 2083 (when exhaustion occurs) as a share of world GDP.

The privately owned share of the global energy flow is a private asset. This asset together with government bonds and capital represent the model's total private assets. Individuals may hold negative assets, on which they pay the domestic interest rate, so there is technically also a fourth asset (private debt), but this is in zero net supply. Arbitrage ensures that all assets earn the same return and that agents are indifferent with respect to the division of their holdings of the assets. 
This precludes the need to keep track of each agent's portfolio.

\subsection{The Production Sector}

Each region's GDP equals the sum of its endowment flow $X(t)$ and aggregate non-energy output $Y(t)$ :

$$
G D P(t)=Y(t)+X(t)
$$

Non-energy output is produced via a Cobb-Douglas technology that uses capital $K(t)$ and skillspecific labor $L(s, t)$, i.e.,

$$
Y(t)=\phi K(t)^{\alpha} L(1, t)^{\beta_{l}} L(2, t)^{\beta_{h}}
$$

where $\alpha$ is the share of capital income in production, $\beta_{l}$ is the share of low-skilled labor input, $\beta_{h}$ is the share of high-skilled labor input, and $\alpha+\beta_{l}+\beta_{h}=1$. The parameter $\phi$ references total factor productivity.

Corporate taxes $T^{k}(t)$ equal the corporate tax rate $\tau^{k}(t)$ times output net of labor costs and depreciation.

$$
T^{k}(t)=\tau^{k}(t)\left[Y(t)-\sum_{s=1}^{2} w(s, t) L(s, t)-\delta_{K} K(t)\right]
$$

Firms maximize profits $\pi(t)$ given by

$$
\pi(t)=Y(t)-\sum_{s=1}^{2} w(s, t) L(s, t)-\left(r(t)+\delta_{k}\right) K(t)-T^{k}(t)
$$

where $\mathrm{w}(1, \mathrm{t})$ is the wage of low-skilled workers, $\mathrm{w}(2, \mathrm{t})$ is the wage of high-skilled workers, and $r(t)$ is capital's rental rate.

Profit maximization requires

$$
\begin{aligned}
w(1, t) & =\beta_{l} \phi K(t)^{\alpha} L(1, t)^{\beta_{l}-1} L(2, t)^{\beta_{h}}, \\
w(2, t) & =\beta_{2} \phi K(t)^{\alpha} L(1, t)^{\beta_{l}} L(2, t)^{\beta_{h}-1}, \text { and } \\
r(t) & =\left(1-\tau^{k}(t)\right)\left(\alpha \phi K(t)^{\alpha-1} L(1, t)^{\beta_{l}} L(2, t)^{\beta_{h}}-\delta_{K}\right) .
\end{aligned}
$$




\subsection{The Government Sector}

Each region's government pays for general expenditures via new borrowing, $\Delta B(t)$, energysector revenue $X_{g}(t)$, and taxes collected from households and firms. General expenditures consist of purchases of goods and services $C^{g}(t)$, payment for pension, health care, and disability benefits that aren't covered via payroll taxes, and interest on existing debt:

$$
\Delta B(t)+X_{g}(t)+\sum_{k=1}^{2} \sum_{a=21}^{90} T(a, t, k) N(a, t, k)+T^{k}(t)=C^{g}(t)+\varrho S B(t)+r(t) B(t)
$$

where $\varrho$ denotes the share of these transfer payments financed by general revenues.

To generate realistic marginal and average corporate tax rates we assume that a fraction of gross corporate tax revenues, $T^{k}(t)$, is rebated to households and included in $T(a, t, k)$ as a lumpsum transfer. The progressivity of income taxation is modelled after Auerbach and Kotlikoff (1987) with marginal income tax rates rising linearly with the income-tax base.

Turning to payroll taxation, let $P Y(t)$ reference the aggregate payroll-tax base. This tax base differs from total labor earnings due to the ceiling on taxable wages. This ceiling is fixed at 290, 200, 155, 300, and 300 percent of average income in the U.S., Europe, Japan+, China, and India, respectively. Japan+'s ceiling is set at Japan's 2012 level (OECD, 2013). For Russia, there is no ceiling.

Average employer plus employee payroll tax rates $\hat{\tau}^{p}(t)$ for the pension, healthcare, and disability transfer programs are determined based on each region's transfer-program-specific budget taking into account general revenue finance, i.e.

$$
\hat{\tau}^{p}(t) P Y(t)=(1-\varrho) S B(t)
$$

Due to contribution ceilings, statutory payroll-tax rates can differ from the average payroll tax rate. Above the contribution ceiling, marginal social security contributions are zero and average social security contributions fall with the agent's income. To accommodate this non-convexity in the budget constraint, we assume that the highest earnings class in each region with a payroll tax ceiling (i.e., all regions except Russia) pays payroll taxes up to the relevant ceiling, but faces no payroll taxation at the margin.

Turning to pension benefits, consider an agent who retires in year $i$ at the exogenously set retirement age $\bar{a}(i)$. Her pension benefit $\operatorname{Pen}(a, t, k)$ in year $t \geq i$ when she is age $a \geq \bar{a}(i)$ is 
assumed to depend linearly on her average earnings during her working life $\bar{W}(i, \cdot)$. Thus,

$$
\operatorname{Pen}(a, t, \cdot)=\nu_{1} \times \bar{W}(i, k)
$$

General government expenditures, $C^{g}(t)$, consist of government purchases of goods and services, including educational expenditures and health outlays. We keep age-specific per capita purchases fixed in efficiency units over the transition. Consequently, aggregate expenditures adjust with changes in the size and age structure of the population.

Age-specific health outlays also grow with $Y(t)$. However, in the U.S., Europe, Japan+, and Russia, we assume an additional growth rate of 1.0 percent per year between 2013 and $2035 .^{5}$ In China and India, age-specific health care outlays per capita are assumed to grow at a faster pace: For the first 35 years after 2013 transition there is an additional annual growth rate of four percent. All government health benefits are treated as government consumption, whereas disability benefits are treated as fungible transfers to households.

During the transition, the governments in the U.S., Europe, Japan+, Russia, and India maintain their initial debt-to-GDP ratios. In these regions we keep the ratio of income-tax to consumption-tax revenue fixed each year and balance the government's annual budget (19) by adjusting the intercept in our linear equation determining the average income-tax rate as well as the consumption-tax rate.

\subsection{Solution algorithm}

Given initial individual asset holdings, our initial guesses of tax rates/tax function parameters as well as of the time paths of region-specific capital stocks, wage rates and marginal products of capital, we first calculate the world interest rate path using the first-order condition determining U.S. demand for capital. We then use this new path for the interest rate to update the capital stocks in all regions except the U.S. Afterwards we solve for household consumption, saving, and labor supply decisions.

Aggregating individual labor supplies in each year provides new time paths of aggregate regionspecific labor supplies. Next we aggregate agent-specific assets at each date to determine a time-path of aggregate world-wide asset holdings. Given capital demand in Europe, Japan+, Russia, China, and India, we can calculate the new capital stock in the U.S. as the difference between world-wide asset holdings and capital demand in the remaining regions. The new values for the aggregate supplies of capital in the U.S. and labor in each region in each year

\footnotetext{
${ }^{5}$ As shown in Hagist and Kotlikoff (2009), this is a rather conservative assumption concerning future growth in benefit levels.
} 
are then weighted with the initial guesses of these variables to form new guesses of their time paths.

The next step in our algorithm is to calculate new wage rates and use the annual revenues and Social Security benefit payments implied by the household decisions to update annual tax rates/tax parameters. We also update corporate tax transfers to households. The algorithm then iterates until the region-specific time paths of capital stocks and labor supplies converge to a fixed point. We give our economy 300 years to reach a steady state. This is ample time as our model reaches a steady state to many decimal places decades earlier. It also converges very tightly around the equilibrium transition path.

\section{Calibration}

This section first presents our demographics calibration. Next we explain the calibration of the model's productive technologies and preferences. Finally, we discuss our fiscal calibration. ${ }^{6}$

\subsection{Population Projections Through 2050}

The main source for population data for all regions apart from Russia's is the medium variant of the United Nations population projections (UNPD, 2014). Demographic data for Russia is based on the average of the UNPD and Rosstat's (the Russian Federal State Statistical Service) projections.

Our model generates a future path of demographics based on the start year of 2008 for which we have population counts by age for each country. The model's age-, year-, and country-specific fertility, mortality, and immigration rates are calibrated to match official projections through 2058. After 2058, fertility rates are endogenously set each year to stabilize total births. This entails gradual changes in fertility rates that lead, over time, in conjunction with our assumed stable net immigration rates, to a stable population and age structure in each region.

As indicated, each country's workforce consists of high- and low-skilled workers. We assume that 30 percent of the U.S., European, Japanese+ and Russian work forces are high skilled. This is in line with figures on educational attainment from Barro and Lee (2001). For China and India we assume that 25 percent of the workforce is high skilled class.

Table 1 compares official and simulated projections of total population, fertility rates, and age structures between 2013 and 2050. Since the model features self-fertilizing hermaphrodites

\footnotetext{
${ }^{6}$ This section draws on Fehr, et. al. (2013).
} 
(agents that reproduce on their own), long-run zero population growth entails a fertility rate of 1 , not 2, ignoring net migration and infant mortality (i.e., each agent needs to reproduce herself, not herself and a sexual partner, to stabilize the population). In reporting the model's regionand year-specific fertility rates, we double the model's rates for comparability with real-world projected rates.

Consider first the official projections of total population counts. Due to relatively high fertility and net immigration, the U.S. population is projected to increase from 320 million in 2013 to 401 million in 2050. This represents a veritable population explosion with the four-decade increase in the number of Americans equaling over 60 percent of Russia's current population.

The Chinese population, in contrast, is projected to rise by "only" 40 million people between 2013 and 2050. The biggest winner when it comes to population growth will be India with a projected increase of 370 million people - far more than the current U.S. population! This will make India the most populous country in the world. In contrast, the EU's population changes very little through mid-century. Finally, Japan+ and Russia populations are projected to shrink by roughly 22 million and 8 million, respectively. For Japan+ this represents a 12.5 percent decline. For Russia the decline is 5.5 percent.

How well does the model reproduce official projections? The answer is remarkably well. In Russia, for example, the model's 2013 population total differs from the official tally by only 0.5 percent. And the discrepancy in 2050 is only about 2 percent. Or consider the EU. In 2013 the model overstates the population count by less than 2 million people. In 2050, there is a larger discrepancy - an 11.4 million underestimate. But, again, this is only a 2 percent differential.

The model also does a remarkably good job tracking region-specific changes in population age distributions. The main exception here is in the share of Russians who are elderly. To keep easy track of bequests, our model requires that parents always predecease their children. As indicated, we set age 68 to be the earliest age at which one can die. At age 68, one's parents are definitely deceased since the youngest parent of a 68 year-old (who gave birth at age 23) would be age 91 . And age 90 is the assumed maximum age of life. Ruling out death before age 68 makes replicating the Russian age distribution particularly difficult given that region's unusually high mortality rates in late middle age.

Consider next the model's fertility rates. These closely approximate official projections. Take China with official fertility rate estimates of 1.66 and 1.81 in 2013 and 2050, respectively. The corresponding model values are 1.68 and 1.85. Or compare Russia's projected increase in fertility from a rate of 1.53 in 2013 to 1.69 in 2050 with the model's 1.48 for 2013 and 1.53 value for 2050 . 
According to official projections all six regions will age dramatically in coming decades. The model does a good overall job reproducing this process. For example, the share of Russia's population over age 70 will be 13.7 percent in 2050 based on official forecasts and 13.9 according to our model. Or take the EU, whose over-70 2050 population share is officially projected at 22.6 percent and equals 20.9 percent in our model. The model also captures much of Japan's, China's, and India's aging processes where the projected 2013-2050 increases in the age 70-90 population shares are 14.2, 11.7 and 4.9 percentage points. The respective model-generated increments are $13.4,11.0$, and 7.1 percentage points.

\subsection{Simulated Demographics, 2050 and 2100}

Table 2 reports the model's population totals, fertility rates, and age structures for 2050 and 2100. As previously indicated, we adjust all age-specific fertility rates after 2058 (the last year of our official fertility rate projections) by a factor that leads each cohort to produce the same number of births at a given age as the cohort one year older produced at that age. The above in addition to our assumption of constant age- and skill-specific immigration rates (after 2058), lead over time (after 90 years, to be precise), to a stable age distribution as well as population size in each region.

Note that projected population totals in 2100 can differ dramatically from those in 2058. Countries whose older single-age cohorts are larger in size than the number of newborns will experience population declines. The reason is simple. After 2058, all existing cohorts will gradually be replaced by new cohorts of equal size (ignoring any mortality after age 68 ) as the number of newborns in 2058.

Take Russia for example. Between 2050 and 2100 the population shrinks from 134.1 million to 102.1 million! This is true notwithstanding the gradual increase in Russia's fertility rate associated with our assumed post-1958 stabilization of the number of new births. Intuitively, below-replacement levels of fertility mean that there will be fewer child-bearing agents in the future than there are in the present, which, for this discussion, we take to be 2058. To produce the same number of births, these smaller sized cohorts need to have higher fertility rates when they reach their child-bearing ages.

The assumed increase in Russia's fertility rate - from 1.53 in 2050 to 1.79 in 2100 - is substantial. Both rates exceed the current rate of 1.51. Yet the legacy of the precipitous post-Soviet era decline in Russian fertility from its post-1970 high of 2.3, recorded in 1987, to its low of 1.2 , recorded in 1999, spells a Russian population at the close of this century that's almost one third smaller than exists today! In short, even if the Russian fertility rate starts rising at a pretty rapid clip after mid Century, it will be too little too late to keep the country's total population 
at the turn of the Century from shrinking by over 30 percent relative to its current size.

Like Russia, the EU, Japan+, China, and India experience population declines between 2050 and 2100. The EU loses roughly 30 million people, Japan+ loses some 48.6 million, China is down almost a quarter of a million people, and India shrinks by almost 125 million. The U.S., in contrast, experiences a net increase of over 43 million over the second half of the century.

The difference between the Russian demographic transition post 1950 and those of the other four regions reflects differences in their paths of fertility between 2013 and 2050. The EU, for example, is officially projected to experience a significant rise in its fertility rate over this period - from 1.58 to 1.83 . This means that in 2058 the ratio of new births to the number of childbearing agents is relatively high. Post 2058, as these relatively large number of new cohorts populate the childbearing ages, the fertility rate needs to fall to maintain fixed the total number of new births each year.

China and India based on our model's assumptions, experience very similar demographic transitions. Both regions witness their populations' first rise, through mid Century, and then shrink. This is true notwithstanding a higher fertility rate at the turn of the Century than at the middle.

The moral to this story, then, is that populations can fall despite high fertility if there aren't enough people of reproductive age. They can also fall if there are enough people in their fertility years, but these child bearers have low fertility.

The last thing to highlight in the table is that fertility rates in China and India end up above the model's 2.0 long-run population replacement-rate value. This reflects the assumption that these countries will experience net emigration - more people leaving then entering. In the other regions net immigration is positive meaning their ultimate fertility rates are below 2.0.

Each region achieves its long-run population distribution and level in 2148, 90 years after 2058, when total births by age are stabilized. Looking through the entire course of the century, the model predicts dramatic changes in absolute and relative population sizes. Japan's population shrinks by 40 percent, Russia's by 28 percent, the EU's by almost 8 percent, and China's by over 16 percent. In contrast, the U.S. population rises over the century by almost 39 percent. And India's population rises by almost 20 percent.

\subsection{Production, Preference and Policy parameters}

Table 3 shows the parameters of our production technology. Table 4 reports values of preference and policy parameters. Capital's share of production is set according to Institut der Deutschen Wirtschaft (2009). The output shares of the low- and high-skill groups were set to generate a 
roughly 50 percent wage differential between the two groups. The depreciation rate is set at 7.5 percent.

Time-preference rates in the six regions were calibrated to match the model's 2013 regionspecific ratios of private consumption to GDP. However, the time preference rate in China is assumed to grow linearly to the U.S. value of -0.024 in 2023 . The intertemporal elasticity of substitution, the elasticity of substitution between consumption and leisure, and the leisure preference parameters are taken from Kotlikoff, et. al. (2007).

The age- and year-specific productivity profile of a low- or high-skilled worker age $a$ in period $t$ is given by

$$
E(a, t)=\xi(t) e^{4.47+0.033(a-20)-0.00067(a-20)^{2}}(1+\lambda)^{a-21},
$$

This profile is that used by Auerbach and Kotlikoff (1987). Note that the higher is the rate of technological change, $\lambda$, the steeper is the age-ability profile. This captures the role of technical progress in influencing not just the level, but also the shape of longitudinal ageearnings profiles. The labor productivity parameter $\xi$ is country specific. It determines the productivity in a given country of the time-t cohort entering the labor market. The U.S. value of $\xi$ variable is time invariant and normalized at 1 . The calibration of this parameter for other regions is described in the following subsection.

Retirement ages - the ages at which agents stop working and also start collecting their state pensions - are taken from OECD (2014) for the U.S. and Europe, from SSA (2010) for Japan+, China, and India, and from the Russian Ministry of Finance.

\subsection{Calibrating Government and National Accounts}

We chose region-specific values for the following parameters to match official government and national account data in 2013 as closely as possible: the initial productivity parameter, $\xi$, the time preference rate, $\delta$, income and corporate tax rates, the mix of income versus consumption taxes (that we use in stabilizing debt-to-GDP ratios), the percentage in each region of corporate taxes that is rebated, the pension-income replacement rate, the share of fossil-fuel endowment flow contributing to the GDP of each country, the share of energy revenues collected by each government, the overall contribution of fossil fuels to GDP, and the initial levels of disability, health, education, and other government expenditures.

GDP (PPP) is taken from IMF (2014). Government revenue and expenditure data as well as other national account data for Europe, Japan+, Korea and the U.S. are taken from IMF (2014) and the World Bank's World Development Indicators (WDI, 2015). For some regions the reported data reflects our best judgment about how to classify expenditures by functions. 
For China, India and Russia, these figures are calculated using publicly available data from their respective ministries of finance following the GFS manual. Energy-sector rents are the sum of World Bank oil, gas and coal resource rents, defined as the difference between revenues and extraction costs for the year 2012 (World Bank, 2015).

For non-U.S. regions, the initial values of $\xi$ parameter are set to help reproduce the 2013 relative values of GDP and are gradually raised to 1 (i.e., to parity with the U.S.) for each successive cohort of new workers. For Europe, Japan+, China, India, and Russia we assume this adjustment occurs over 25, 25, 40, 95, and 40 years, respectively. We have no solid basis for these choices other than their production of plausible relative GDP ratios in 2050. Our assumption of such a slow catch up for India was influenced by Bosworth and Collin's (2008) finding of very little improvement in elementary education in that country over the past four decades.

Each region is assumed to adjust income and consumption taxes to maintain its 2013 debt-toGDP ratio through time. In 2013, debt-to-GDP ratios are calibrated to match 2013 government net-interest payments. We exogenously set the corporate tax rate to match the official nominal rate. These rates are 40, 22.8, 35.2, 25, 34, and 20 for the U.S., EU, Japan+, China, India, and Russia. But official tax rates are uniformly higher than effective rates. To match actual corporate tax revenues relative to GDP, we assume each nation rebates a percentage of corporate tax revenues as a lump-sum transfer. This rebate is set at 49, 8, 0, 0, 20, and 10 percent, respectively, for the six regions.

The remaining revenue collected in 2013 comes from consumption and income taxes. The consumption-tax shares of these remaining revenues are 53,58, 48, 93, 85, and 75 percent for the U.S., EU, Japan+, China, India, and Russia, respectively. In each year of the model's transition, we multiply the 2013 region-specific consumption- and income-tax shares by the amount of revenues needed to keep debt fixed as a share of GDP in that year. This determines each year's total consumption- and income-tax revenues. The model's annual consumption and income tax rates are then set to generate these revenue amounts.

Our income tax systems are assumed to be progressive with the parameters of each region's income-tax functions set to generate what appears to be realistic average and marginal tax rates. Revenues raised from the income tax satisfy

$$
R_{t}=\tau_{t} B_{t}+\frac{\varphi_{t} B_{t}^{2}}{2}
$$

where $R_{t}$ is total revenues from the income tax, $\tau_{t}$ is the endogenously calculated average income tax rate, $B_{t}$ is total labor income, and $\varphi_{t}$ an exogenously set progressivity term. For the U.S., the EU, and Japan this takes the value 0.3. For the other three regions it is 0 . 
Under this calibration the 2013 average U.S. income tax rate is 13.1 percent and the average marginal income tax rates on unskilled and skilled workers are 24.5 and 34.1 percent, respectively.

Outlays of social security systems were calibrated to yield official values from the IMF (2014) and WDI (2015). The level of benefits is calibrated by setting the pension replacement rate. The replacement rates for the U.S., EU, Japan+, China, India, and Russia are set at 71.7, 81.5, $24,27,60$, and 63 percent respectively. The percentage of pensions paid via a dedicated payroll tax is constant and calibrated based on the 2013 ratio of payroll tax revenues to benefits. For the U.S., 35 percent of pension benefits are paid via general government revenues. For the EU, Japan+, China, India, and Russia the percentages are 6.4, 5, 40, 55, and 21, respectively.

Due to data limitations we use the German age-specific education profile for all regions in the model and re-scale the profile on a country-specific basis to get realistic education outlays in year 2013 in each region. Education expenditures and 'other expenditures', which include military spending and other government services, are calibrated in the same way. We assume the level of disability transfers grows with the rate of technological growth, health expenditures grow as described above, and we assume education and other expenditures remain constant as a share of non-fossil fuel output (GDP less energy sector rents).

In calibrating health expenditures, we apply the Japanese age-specific government health care expenditure profile for Japan+ as well as for China and India. In the case of Europe, we use the German profile. For the U.S. our profile comes from Hagist and Kotlikoff (2009). The Swedish profile from that study is used for Russia. These profiles are then multiplied by a country-specific factor to reproduce the 2013 ratio of health expenditures to GDP.

We assume, for all countries, that disability benefits paid per agent are the same regardless of age. The level of disability benefits in each region is calibrated to match the 'other transfers' share of national public expenditures.

In addition to these parameter values, our model requires an initial distribution of assets by age and income class for each region. We generate the country-age-income class asset distribution by calculating the steady state of the model using 2008 demographics and parameters. The level of each region's asset profile is then adjusted to generate plausible interest rates and ratios of assets between regions. Regions' aggregate share of world assets in the baseline path are given in table 12.

Finally, the model's 2013 ratio of household consumption to GDP is calibrated by adjusting the time preference rate of different regions. 
Table 5 compares the model's 2013 values of GDP and other variables with actual values. Each country's GDP, including GDP from its energy sector, is presented as a share of U.S. 2013 GDP.

As the table makes clear, the model generally does a very good job matching actual 2013 relative GDPs and ratios of private and government consumption to GDP. And it does a reasonable job matching actual aggregate- and category-specific expenditure ratios to GDP. Since either revenue must adjust to expenditures or the other way around, one can't separately calibrate on both revenues and expenditures. We chose to calibrate on expenditures, which is why they match up to actual data far more closely than the model's endogenously determined revenue amounts.

\section{Findings}

This section presents the model's baseline predictions. Next it examines the consequences of a 50 percent unanticipated, but permanent decline in fossil-fuel prices. It then considers the impact of using debt finance to keep tax rates temporarily fixed in response to this shock. Thereafter, it considers the consequences of three hypothetical Russian policies - pension reform, corporate tax reform, and policy-induced changes in the fertility rate. The section concludes by evaluating the impact of implementing all three policies in the presence of a permanent 50 percent fossil-fuel price shock.

Note that in all scenarios the amount of sovereign debt in 2013 is held at the baseline level. Debt-to-GDP ratios (except in the deficit finance case) are then calculated and fixed at a new level determined by how GDP in 2013 adjusts to the shock. We model scenarios in which energy prices fall in half by simply cutting the flow of energy output in half. ${ }^{7}$

\subsection{GDP in the Baseline Transition}

Table 6 shows, for each country, the evolution of GDP, the capital stock, labor supply, and tax rates along the baseline path. GDP, capital stocks, and labor supplies are written as ratios of

\footnotetext{
${ }^{7}$ Note that were we to explicitly model energy as a separate good with its own relative price, a change in that relative price would not entail a global, i.e., economy-wide wealth effect. The reason is that the physical economy wouldn't change. There would be the same amount of physical capital and energy reserves in our six-region world. The relative price change would, however, visit offsetting wealth effects on young and older cohorts as well as agents in different regions. In this model, since we ignore the relative price of energy, we approximate the energyprice shock by not only cutting in half of the stream of energy output from 2013 through 2083 . We also increase the world's stock of capital by over 4 percent to roughly approximate what would arise were we to explicitly model energy as a distinct commodity. This permits us to focus on the point of interest - the redistribution away from Russians toward the rest of the world.
} 
their 2013 U.S. counterparts. Thus, India's value of GDP in 2100 indicates that its economy is 9.62 times larger than the U.S. economy was in 2013. Labor supplies are measured in effective units, i.e., they take into account country- as well as cohort-specific labor productivity.

Based on the table, our model's 2013 global GDP is just over 4 times that of the U.S. in 2013. By 2100, it's 27.7 times 2013 U.S. GDP. Hence, the model is predicting tremendous economic growth over the rest of the century on the back of productivity catch up of and larger population entering the labor force mainly in China and India. Altogether the model predicts total output rising by over a factor of 7 !

The model also predicts a vastly different long-run world order. In 2100 the U.S. share of global GDP is no longer what it is today, namely 25 percent. Instead, it's less than 13 percent. The EU faces a very similar decline in its share of global GDP.

What about Japan? It's economy accounts for less than 10 percent of global output in 2013 and less than 3 percent in 2100. In 2013, China's output is 2.5 Japan's output. In 2100, it's almost 14.5 times Japan's output.

Japan's productivity does catch up to the U.S.'s. But when it comes to the relative size of its economy, this productivity catch up is not enough to offset the decline in the number of Japanese workers. Whereas Japan's GDP is 39 percent of U.S. GDP in 2013, by the end of the century, it's only 18 percent.

Russia's economy also shrinks compared to the global economy. Currently its economy produces 5 percent of total global output. By 2100 this figure drops to 3 percent.

Thanks to China's fast productivity catch up and India's massive population growth, the East economically eclipses the West by mid century. And by the end of the century the East represents the bulk of the global economy. Taken together, the GDPs of China and India account for 34 percent of 2013 global output. In 2100, the two countries account for 67.6 percent of global output. In 2100, these two nations and Japan+ account for seventy cents of every dollar of global GDP.

The explanation for these striking results lies in differences across the regions in population growth and degrees of labor productivity catch up. In Japan, for instance, population falls by roughly 70 million people between 2013 and 2100. India's population, in contrast, rises by over 400 million. This exceeds the total current U.S. population! 


\subsection{Understanding the Sources of Growth Along the Transition}

General productivity growth - the 1 percent growth in the time endowment discussed above would, by itself, raise global GDP, but only by a factor of 2 . The remaining growth is due to our assumed productivity catch up, capital accumulation, and global population growth.

The big growers are, of course, China and India, albeit not exactly following the same patterns. India, though far more populous by 2100 , is still less productive than the U.S. due to our assumption of slower labor-productivity catch up and the fact that once catch up occurs for new cohorts, it takes roughly four decades for all workers in caught-up regions to have the same productivity as same-aged workers in the U.S. In contrast, by 2100 , China is fully caught up, while India still has several decades to go. Nonetheless, India's 2100 GDP is only slightly lower than China's thanks to its larger projected population.

The productivity catch up is clear when observing the relative growth across regions in the total effective labor supplies of low- and high-skilled workers. Take China and Russia. The Chinese and Russian populations both shrink relative to that of the U.S. But the effective U.S. workforce grows to the end of the century by a factor of roughly 3.5 whereas the Chinese and Russian effective work forces grow by factors of roughly 10 and 5, respectively.

Japan also experiences catch-up growth, but its catch up is smaller. Its population also shrinks through time due simply to their demographic transition, characterized by a declining young population. Consequently, Japan's effective labor force grows at a slower rate than that in the U.S., which experiences rapid growth in workers, but zero catch up growth in productivity.

Changes through time in the model's country-specific capital stocks generally align with changes in each country's effective labor supply. Table 7, which shows relatively stable pre-tax marginal products of capital and labor confirms this point. Consider, for example, the gross marginal product of capital in the U.S., which depends on the capital-labor ratio. It is 17.5 percent in 2013 and 16.7 percent in 2060.

Note also that the differences across the regions in gross marginal products reflect differences in their marginal (before rebate) corporate income tax rates. Moreover, since capital's international mobility leads to equalization across regions in the post corporate-tax return to capital (as confirmed in Table 7), regional differences in pre-tax returns (the marginal products of capital) arise due to differences across regions in rates of corporate income taxation.

Table 7 also shows the marginal products of labor per unit of effective labor supply. There are interesting and easily explained regional differences here. For example, the U.S., thanks to its 
relatively high corporate income tax rate, has less capital per worker and, therefore, somewhat lower marginal products of low-skilled labor compared with EU or Russia. Another interesting feature is the relatively high marginal products of skilled workers in China and India. This reflects the initial and assumed ongoing scarcity of skilled relative to unskilled workers in these regions.

The final point to make about Table 7 concerns differences in wage rates (of 30 year-olds) across the six regions at a point in time as well as over time. The marginal products of labor tell us the extra output that a 30 year old of a particular skill type who is endowed with the productive capacity of an equally skilled 30 year-old U.S. worker would produce in the specified country in the year under consideration.

But a 30 year-old skilled (unskilled) worker in a given country in year $t$ won't be as productive as her counterpart in the U.S. until the productivity catch up phase in her country is complete. Consequently, the wage rates in the non-U.S. countries are considerably lower than in the U.S. in 2013 and for many years thereafter until the catch up is complete. In Russia in 2020, for example, a thirty year-old low-skilled worker earns only 29.7 percent of her U.S. counterpart. But by 2060, the gap is closed, indeed, more than closed. Russian wages are higher thanks to its higher marginal products of labor, which, in turn, are due to a larger ratio of capital to labor in the country, which, in turn, is due to Russia's relatively low corporate income tax.

\subsection{Fiscal Dangers Along the Baseline Transition}

Although the baseline transition path provides good news when it comes to global output growth, four of the six regions, the U.S., EU, Russia, and India, face extreme fiscal challenges in the next hundred years. Table 6 displays income, pension, and consumption tax rates across regions and time. It shows that in these four regions, each of these tax rates rise over the century. Table 8 combines these tax rates in a single total effective income-tax rate measure. The table presents the values of average (across all workers of all ages) effective income-tax rates as well as the average marginal effective income-tax rate for each region in the year specified. These are weighted averages with the weighting based on workers' earnings.

In the U.S. case, the sum of the income, pension, and consumption tax rates is 37.6 percent in 2013, where the consumption tax is measured as an equivalent tax on income. ${ }^{8}$ This total rate rises through 2100 to 64.0 percent! Moreover, the average marginal tax rates are 49.0 and 49.7 percent respectively for unskilled and skilled U.S. workers in 2013. By 2100, the corresponding tax rates are 75.2 and 70.7 percent. Russia follows a similar pattern, with the average effective wage-tax rate increasing from 37.8 to 72.3 percent over the century, for both unskilled and

\footnotetext{
${ }^{8}$ Specifically we add the income tax and the social security tax rate to $\frac{\eta}{1+\eta}$ where $\eta$ is the consumption tax rate
} 
skilled workers. Why are these U.S. marginal tax rates on the much higher paid skilled workers initially slightly higher and ultimately lower than those of the unskilled workers? The answer is the ceiling on taxable pension income that leaves high skilled workers paying no payroll tax at the margin.

One might wonder how the model can converge with such high marginal tax rates. The answer is that income and substitution effects largely offset one another, i.e., the need to work due to the income loss from having to pay higher taxes balances out in large part against the incentive to substitute leisure for consumption.

Although the model converges, which says its global economy can withstand much higher average and marginal tax rates than now prevail, the model excludes a key factor that should give one pause. In its current incarnation, the model posits neither tax avoidance nor tax evasion. Were we to incorporate these two important factors in the model (which is on our immediate research agenda), financing projected future expenditure might well be unfeasible.

Unsustainable fiscal policy means a government can't satisfy its intertemporal budget along its transition path, i.e., it can't, as a present value matter, collect enough taxes through time to cover its path of expenditures, also valued in the present. But having the government off its budget constraint, while having households satisfy theirs, implies that the economy is off its budget constraint and is trying to consume more in present value than the present value of its resources - its physical plus human capital. Human capital references the present value of all of the economy's future labor earnings. Our reading, then, of these fiscal tax-rate results is that they portend very major macroeconomic and political problems through time.

The rise in the total effective tax rate is less pronounced in the EU. The 2013 average is 57.1 percent, 1.5 times larger than the U.S. value. This narrows by 2100 , when the EU total effective wage tax rate is 1.2 times that of the U.S. Thus the U.S. starts with a much lower total effective wage tax rate, but, at century's end, it closes the gap. The explanation here involves our assumed productivity catch up in the EU. Because the EU's productivity converges to that of the U.S. over the course of 25 years, in the year 2100 all EU workers have U.S. levels of productivity. However, pension benefits are calculated based on the lifetime wage of retirees and in 2100 reflect Europe's previously lower productivity.

Japan+'s fiscal transition is less dramatic than the EU's. Like the EU, the region gets older from a position of already being quite old. Hence, the fiscal impact, measured on a percentage basis, is not as substantial as in the U.S. or China. Additionally, Japan+'s catch-up productivity growth proceeds in the same time frame as in the EU. Consequently, the fiscal impact of having such a large elderly population in 2100 is mitigated by the assumed higher productivity of its 
workforce. In Japan+, the average total effective income tax rate is 38.1 percent in 2013 and 46.0 percent in 2100. Japan+'s high skilled workers face a higher marginal rate throughout the transition, as pension taxes are a smaller share of Japan+'s total taxes. Japan+'s consumption tax rate (Table 6) is able to decrease while keeping revenues high because of a dramatic increase in private consumption. In fact, Japan +'s consumption's share of GDP rises from 57.8 percent in 2013 to 79.6 percent in 2050! This is due to the retirement of large numbers of Japanese retirees who, due to their advanced ages, have very high propensities to consume.

India also experiences a major hike in its total effective wage-tax rate, but it takes place primarily in the second half of the century as fertility rates gradually adjust and the country gradually becomes roughly as old as its trading partners. China's fiscal transition is relatively benign thanks not to its aging, which is the most significant of any of the six regions, but to its assumed rapid and very significant catch-up growth.

\subsection{Russia's Fiscal Transition}

Of the six regions, Russia faces the greatest challenges in financing government expenditures over the rest of this century. In 2013, its population age 60 and over accounts for less than 18 percent of the total. But by 2050, this age group represents over 34 percent of all Russians.

Other things equal, this should produce a major rise in the payroll tax needed to fund the Russian pension system. Even with Russia's assumed catch up productivity growth this materializes, for instance while in 2013, the average equivalent total wage tax rate in Russia is 37.8 percent, in 2060, it's 54.1 percent.

Russia's fiscal crunch worsens after 2083 with the exhaustion of fossil fuel reserves in Russia as well as in the other regions. By 2100 the average total effective wage tax rate is 72.4 percent. The increase in the Russian tax rate after 2060 has three main drivers. On the one hand, more than half of the increase reflects the loss of fossil fuel receipts. The other half reflects both, the projected continued aging of Russia after 2050 and our assumed growth in health care benefit levels.

Russia, it should be noted, already has a very major problem with tax evasion. Its informal sector is very large as reflected by the difference in its 22 percent $^{9}$ statutory payroll tax rate and its 13.6 percent 2013 effective payroll tax rate. Hence, the prospect of a massive increase in tax rates toward the end of the century is particularly challenging for Russia.

Russia also experiences important changes in national saving. From a base of about 51 percent

\footnotetext{
${ }^{9}$ This tax is designated to finance state pensions. http://www.ssa.gov/policy/docs/progdesc/ssptw/20122013/europe/russia.html
} 
of GDP in 2013, private consumption decreases to a low of 43 percent of GDP in 2063. This is due to Russians increasing their savings in anticipation of hard times. Subsequently, however, Russian private consumption increases steadily to about 47 percent of GDP after fuel's exhaustion in 2083. This is due to Russian aging and the larger propensity to consume of the elder.

\subsection{Fossil Fuel Price Shock}

In this section we assume that fossil-fuel output permanently falls in half starting in 2013. Again, this is an approximation to the impact that would arise were we to explicitly model energy as a distinct commodity and consider a halving of its relative price. This reduction in fossil-fuel income disproportionately impacts Russian government finances. Russia's debt to GDP ratio increases by 6.5 percent immediately.

Unsurprisingly, the change has a sizable negative impact on Russian welfare. Welfare for a skill- and country-specific cohort born in year $t$ is measured as a compensating differential. The compensating differential measures the percentage change in annual consumption under the baseline simulation needed to achieve the same utility gain or losses as arise in the transition under consideration. This measure is presented for a selection of Russian birth cohorts in Table 13.

In 2013, Russian GDP is 6 percent below its baseline level (Table 9), representing a $\$ 200$ billion decline in Russian GDP. However, the Russian economy recovers over time. In 2080, Russia's GDP is only 1.4 percent below its baseline level. This reflects increased labor supply as Russians respond to the loss of income associated with their now higher taxes.

The halving of fossil-fuel output entails a reduction in the present value of income from energy assets. This means that more of workers' savings are crowded into capital. This is particularly beneficial to Japan+, which benefits from the larger world capital stocks but has negligible fossil fuels of its own. Its 2013 GDP rises by 1.5 percent. However, by 2040 Japan's capital stock is pretty close to its baseline level.

While all Russians alive in 2013 are hurt by the decline in the fossil fuel price, elderly Russians are hurt the most. Cohorts entering retirement between 2008-2018 are worst off, with the low skilled retiring in 2015 facing a nearly 6 percent reduction in lifetime utility, while future generations are impacted to a lesser extent. This is because the old face higher consumption taxes, which must be raised to make up the shortfall. The young must pay higher taxes as well, but they have more time to adjust their labor supply and saving. Future generations are little affected compared with the baseline as fossil fuels exhaust in any case in the baseline. Other 
nations of the world are barely affected.

As stated, the main mechanism for the immiseration of the Russian old is an increase in taxes. Spending is left unchanged so tax rates must increase to make up for the loss of fossil fuel revenue. Consumption taxes are 44 percent higher and income taxes 33 percent higher in 2013 as a result of the changes.

\subsection{Using Debt Finance to Buy Time}

A permanent collapse in fossil fuel revenues leaves Russia in a particularly tenuous position. If, as assumed above, Russia chooses not to make cuts to spending, then it will need to increase taxes, institute growth-enhancing reforms, or resort to debt finance. Here we consider debt finance. In this scenario Russia fixes all non-pension tax rates at their 2013 no-fossil-fuelshock levels for 10 years. This leads to a dramatic expansion of Russia's debt-to-GDP ratio, placing an even larger repayment burden on future generations while shielding current older generations from immediate tax hikes or spending cuts.

Absent additional revenue or expenditure cuts, Russia's public sector immediately runs higher deficits. In fact, its primary balance falls from a surplus of 0.6 percent of GDP to a deficit of 5.4 percent of GDP. This raises the overall deficit to 6.3 percent of GDP. For the next 10 years, the gap between revenues and non-interest expenditures rises, raising the primary deficit to 9.5 percent of GDP in 2023, the last year of deficit finance. Moreover, interest payments increase by an average of 20 percent annually, driving the peak overall deficit to 14.7 percent of GDP. Given this 10-year period of persistent high deficits, public sector debt explodes from 17 percent of GDP to 115 percent of GDP. Indeed, in this scenario, Russian interest payments in 2024 total 5.7 percent of GDP versus 0.7 percent in the baseline. Assuming spending isn't cut, taxes must be raised dramatically after 2024 to handle both the ongoing revenue shortfall and interest on the additional debt.

Temporarily keeping tax rates low is good for current retirees but places a larger burden upon future generations. The impact on current retirees of the fossil-fuel shock is roughly cut in half. The first generation to suffer, compared with facing the energy-price shock without debt finance, is the generation born in 1940 . The generation born in 2100 , which is relatively unaffected by the fossil fuel shock in the previous scenario, finds itself about 5 percent worse off due to having to help make permanently higher interest payments on the national debt. 


\subsection{Russian Corporate Tax Reform}

An alternative approach to addressing a permanent fossil-fuel price shock is to undertake reforms that boost economic growth. Such policies can expand the tax base improving the medium and long-term fiscal revenues and easing the fiscal burden for future generations. One such policy would be to reduce the corporate income tax while raising personal income taxes to make up for reduced revenue not recouped via induced economic growth.

In order to exemplify how a corporate tax reform may render better outcomes, in this chapter, the model simulates a reform that eliminates the corporate tax. This policy dramatically boosts foreign investment in Russia. ${ }^{10}$ The extra capital put to work in the country makes labor more productive. This boasts the demand for labor producing significantly higher real wages.

Table 9 shows the impact on GDP in the six regions of eliminating the corporate tax. As before, a combination of income and consumption taxation is used to make up revenue shortfalls in each country. The table presents, for each country in selected years, baseline values of GDP, values of GDP after the fossil fuel price shock, and values of GDP arising from each hypothetical Russian policy reform as well as from combining all reforms. As Table 9 makes clear, the corporate tax reform leads to an immediate and sizable boost to Russia's economy. In fact in 2013, Russia's GDP is 5.4 percent higher than in the baseline.

Finally, this reform differentially affects different birth cohorts. For example, generations that are about to retire (those born around 1955) are made 3.7 percent worse off as a reduction in corporate taxes must be made up for through increases in consumption and income taxes. In fact, the model shows that income and consumption taxes are 6.3 and 17.8 percent, respectively, higher in 2013 as a result of the reform. But future generations benefit from the change. The generation entering the workforce today (born around 1990) is 1.4 percent better off as a result of the change. The generations born just on 1975 are the oldest to see a universal benefit from corporate tax reforms.

\subsection{Russian Pension Reform}

Another strategy for boosting Russia's long-term welfare is pension reform. Russia's current "pay as you go" pension system taxes workers to pay for the pension needs of the current elderly. As Russia's population ages, this places an increasing burden on Russia's workers. One option for preventing this crisis would be to slowly phase out the current pension system and replace it with a system of personal retirement accounts that are invested globally, but passively (i.e., in index funds). Kotikoff proposes such a system at www.thepurplesocialsecurityplan.org.

\footnotetext{
${ }^{10}$ The potential for such investment in the real world clearly depends on geopolitical factors.
} 
Because private net saving arising is ultimately privately determined, we can model this possible pension reform simply by gradually eliminating the current pension system. I.e., there is no need to go beyond this and model the personal accounts, contributions to which can be viewed simply as a component of each worker's total private saving in each year.

In this simulation we consider a slow phase out of the Russian pension system beginning in 2013. Starting in that year, every generation reaching retirement age receives a slightly less generous pension. More precisely, we linearly reduce by 3 percent per year the pension replacement rate for each cohort as it enters retirement. The generation retiring in 2034 is the first to receive zero benefits, but grandfathered benefits are still being paid to earlier retirees through 2065.

The goal of this reform is to gradually raise national saving, wealth accumulation, and lower taxes. The reform hurts those about to retire, but helps those who have not yet begun working. Unfortunately, because of capital is mobile internationally, increases in Russian saving arising from the reform have only a very small impact on the amount of capital that actually ends up being invested in Russia. As a result of the reform Russian GDP will be only about 50 billion dollars higher than the baseline in 2040. In the year 2100, GDP is almost a full trillion dollars lower. Other countries benefit from increased Russian saving. U.S. GDP slightly improves and in 2040 is about 160 billion dollars higher. After 60 additional years, U.S. GDP is 500 billion dollars larger.

Unsurprisingly, phasing out the current pension system reduces total government spending considerably. After 2065 state pension spending is zero. In the baseline simulation the level of pension spending is 9.9 percent of GDP in that year. Other elements of spending are unaffected. Pension taxes plummet as a result of these changes.

The increase in personal saving induced by the pension reform permits much larger consumption over time. In 2100 Russian private consumption as a share of GDP is 71 percent rather than 56 percent. However, not everyone enjoys the same positive effects on welfare. Those nearing retirement are negatively impacted. The generation born in 1970 is worst off with their lifetime welfare reduced by about 9.8 percent. This and similarly aged generations neither had the time necessary to build up precautionary savings nor are they young enough to be helped by lower pension tax rates. The generation entering the labor force in 2013 is roughly indifferent to pension reform, while subsequent generations benefit. Lower tax rates allow Russians to consume more and work less. GDP is marginally lower in the long run thanks to this reduction in labor supply. Indeed, in 2100 labor supply is about 8 percent below its baseline level. 


\subsection{Russian Fertility Increase}

The Russian government's attempts to raise the nation's fertility rate have, so far, met with limited success. Yet, it is interesting to investigate what a successful fertility policy would achieve.

A higher fertility rate would, over time, ease the burden of supporting Russia's elderly and the financing of other government spending commitments. On the other hand, higher fertility means a larger economic burden on Russia's young parents who will be forced to sacrifice - to consume less and work more - to provide for their additional children.

One thing Russia need not worry about, assuming it remains open to foreign investment, is that a larger long-run work force would depress Russian wages. The reason is that additional capital would flow into Russia to maintain Russian labor productivity.

To see what higher fertility would mean for Russia we reran our model assuming a 25 percent increase in Russian fertility rates at all ages through 2058. After 2058 we assume the higher level of births prevailing in 2057, which are associated with the assumed higher fertility rates, continues into the future. This change in demographic assumptions produces a much younger as well as much larger (indeed 40 million larger) Russian population in 2100 than in the baseline projection.

The economic impacts of such a successful fertility policy are shown in Table 9. As with the other hypothetical policies considered, the rest of the world is little affected by higher Russian fertility. But, over time, the impact on the Russian economy is substantial. In the year 2100, Russian GDP is almost two fifths larger than it would otherwise have been. And the total effective wage-tax rate in that year is 69 percent smaller than baseline.

This assumed successful higher fertility policy also has striking generational implications. Current retirees are not particularly hurt or helped by the increase in fertility. But young agents, at the time the policy is initiated, face a different fate. Their welfare as measured by utility from consumption and leisure falls significantly as they find themselves consuming less and working more to pay for their additional children. And since their extra children and those of others don't contribute to the economy for decades, there is no near-term decline in taxation to offset their additional child-rearing costs.

Consider, as an example, those born in 1995. They experience a 5.8 percent welfare loss. Future generations increasingly benefit from the expansion in the tax base. The generation born in 2030 is the first to benefit from the change, with generations after that experiencing 
even larger welfare gains.

\subsection{Combined Scenario}

In this simulation we implemented all three reforms simultaneously. But we did so in the context of the previously posited permanent decline in fossil-fuel rents. While there are no clear synergies between these policies, their combination is interesting to consider for a simple reason. They each have the ability to ameliorate different long-run economic conditions.

As Table 9 shows, of the three policies, only the higher fertility rate produces a major long-run increase in Russian GDP. On the other hand, as Table 11 indicates, when it comes to raising wage rates, eliminating the corporate income tax is the most effective tool. This is thanks to the major inflow of foreign capital (which makes Russian workers more productive) to Russia in response to Russia's becoming a corporate tax haven. As for pension reform, it, combined with the fertility increase, produce much lower long-run effective taxation of labor supply. In fact, the effective wage-tax rate at the end of the century is less than half its baseline value.

Losing pension benefits is no light matter. So in this three-policy simulation, it comes as no surprise that initial retirees suffer and future generations benefit. The first generation to come out ahead, despite the permanent decline in the price of fossil fuel is the cohort born in 2015 . The cost of these reforms is, however, quite steep for initial older generations. An example is the cohort born in 1965, which suffers a 14.8 percent reduction in its welfare. However, the gains to future generations are remarkably large. The generation born in 2100 is over 33.5 percent better off than it would be without the implementation of the three policies.

To summarize, in combination, the three policies can deliver a considerable long-run improvement in Russian economic conditions. And this remains true even in the face of a significant permanent reduction in the price of fossil fuels - Russia's most significant export.

\section{Conclusion}

This paper simulates Russia's transition within a global economic setting featuring the U.S., the EU, China, India, and Japan plus Korea. The model predicts vast changes over time within this six-region economy. In particular, the economic ascendancy of China and India transforms the other regions into small players on the global economic stage.

While the Russian, EU, and U.S. economies grow at very similar rates, these rates are dramatically lower than those in China and India. In 2100, these two regions produce almost two thirds 
of total six-region output - up from one third in 2013. Thanks to its remarkably large projected decline in population, the combined Japanese/Korean economy is unable to keep up even with the Western economies.

Despite Russia's challenges with respect to its relatively high energy dependence, the country grows more rapidly than the U.S. over most of the the century. In 2013, Russia's GDP is 20.0 percent of the U.S. GDP. In 2040, it's 22.9 percent. In 2083, it's 26.2 percent of U.S. GDP and then drops to 25 percent in 2084, when fossil-fuel exhaustion occurs. In 2100 Russia's GDP is 23.6 percent of the U.S. level.

Given the remarkably rapid projected growth in the U.S. population and the projected major decline in the Russian population, Russia's ability to keep pace economically reflects assumed catch-up productivity growth. Specifically, we assume that over the next 40 years new cohorts of Russian workers will become as productive as new young cohorts of U.S. workers. Whether this assumption proves true will depend critically on near-term educational policies in both Russia and the U.S.

The fact that both the Russian and the U.S economies are predicted to grow substantially over the remainder of the century is this study's good news for citizens of these two regions. The bad news is the massive tax hikes both regions face unless policy is quickly changed.

Both the U.S. and Russia face major fiscal challenges over the course of the Century. In the U.S. government expenditures associated with population aging require massive hikes in tax rates. In Russia, population aging also takes a fiscal toll. But fossil-fuel depletion and the potential for permanently lower fossil fuel prices make Russia's fiscal finances particularly precarious. Whether either country can weather its coming fiscal storms without the types of reforms examined here is very hard to say.

With no change in policy, average tax rates in both countries will nearly double over the Century. Marginal effective wage-taxation will also rise to levels that provide far greater incentives for tax avoidance and tax evasion. This points calls into question the sustainability of long-term fiscal policy in both countries.

The U.S. and Russia are not alone when it comes to running what may be unfeasible fiscal policies. The EU and India are in much the same boat. Tax rates in China and Japan are also projected to rise over time, but less dramatically. This is true despite rapid aging in both countries. But the population share of the elderly is not the only factor at play. The share of younger dependents in the population also matters. So does the age-pattern of government transfer payments. Another key factor is the country's reliance on particular taxes to cover 
its spending. Finally, the precise demographic changes each region faces (and they are each unique) determine the size of particular tax bases at different points in time.

In sum, real world economies and models of them have a lot going on. Only large-scale simulation models of the type presented here can capture the major, highly complex, and interconnected factors at play in economies experiencing rapid changes in productivity, demographics, fiscal policies, and factor prices. Although such models are, by necessity, black boxes, they are black boxes whose equations can be carefully checked and that will only work (as in converge) if all budget constraints are satisfied at each point in time and all optimality (first order) conditions hold. This is certainly the case in the model presented here. Consequently our model's warning about current fiscal policies potentially pushing countries, including Russia, into deep insolvency needs to be fully heeded. 


\section{References}

Abel, Andrew B. and Laurence J. Kotlikoff. (1994). "Intergenerational Altruism and the Effectiveness of Fiscal Policy: New Tests Based on Cohort Data," in Savings and Bequests.

Altonji, Joseph G., Fumio Hayashi, and Laurence J. Kotlikoff. (1992). ’'Is the Extended Family Altruistically Linked? Direct Tests Using Micro Data," The American Economic Review 82(5), 1177-1198.

Altonji, Joseph G., Fumio Hayashi, and Laurence J. Kotlikoff. (1997). "Parental Altruism and Inter Vivos Transfers: Theory and Evidence," The Journal of Political Economy 105(6), 1121-1166.

Aglietta, M., Borgy, V., Chateau, J., Juillard, M., le Cacheux, J., Le Garrec, G., and Touze, V.(2007). "Asian Catch Up, World Growth and International Capital Flows in the XXIstCentury: A Prospective Analysis with the Ingenue 2 model”, Working Paper No. 2007 - 01,CEPII.

Altig, D., Auerbach, A.J., Kotlikoff, L.J., Smetters, K.A. and J. Walliser. (2001). "Simulating Fundamental Tax Reform in the United States", American Economic Review 91, 574-595.

Auerbach, A.J. and L.J. Kotlikoff. (1987). Dynamic Fiscal Policy, Cambridge University Press, Cambridge.

Auerbach, A. J., Kotlikoff, L. J., Hagemann, R. P., and Nicoletti, G. (1989). "The Economic Dynamics of an Ageing Population: The Case of Four OECD Countries", Economics Department Working Paper No. 62, OECD, Paris.

Barro, R.L. and J.W. Lee. (2001). "International Data on Educational Attainment: Updates and Implications", Oxford Economic Papers 53, 541-563.

Beetsma, R., Bettendorf, L., and Broer, P. (2003). "The Budgeting and Economic Consequences of Ageing in the Netherlands", Economic Modelling, 20(5), 987-1013.

Borsch-Supan, A., Ludwig, A., and Winter, J. (2006). ”Ageing, Pension Reform and Capital Flows: A Multi-Country Simulation Model”, Economica, 73(292), 625-658.

Bosworth, B. and S.M. Collins. (2008). "Accounting for Growth: Comparing China and India", Journal of Economic Perspectives 22, 45-66.

Bradford, D.F. (1978). "Factor Prices may be Constant but Factor Returns are Not", Economics Letters 1, 199-203. 
Brill, A. and K.A. Hassett, (2007). "Revenue-Maximizing Corporate Income Taxes: The Laffer Curve in OECD Countries", AEI Working Paper No. 137.

Broer, D. P., and Westerhout, E. W. M. T. (1997). "Pension Policies and Lifetime Uncertainty in an Applied General Equilibrium Model”, in D. P. Broer and J. Lassila (eds.), Pension Policies and Public Debt in Dynamic CGE Models, Heidelberg, Physica.

Brooks, R. (2003). "Population Aging and Global Capital Flows in a Parallel Universe", IMF Staff Papers, 50(2), 200-221.

Council for Economic Planning and Development (CEPD). (2007). "Population Projections for Taiwan Area 2006-2051", http://www.cepd.gov.tw/

De Nardi, M., Mrohoroglu, S., and Sargent, T. J. (1999). "Projected U.S. Demographics and Social Security”, Review of Economic Dynamics, 2(3), 575-615.

Diamond, John W. and George R. Zodrow. (2012). ”Dynamic Overlapping Generations Computable General Equilibrium Models and the Analysis of Tax Policy: The Diamond Zodrow Model," in Peter B. Dixon and Dale Jorgenson (ed.),Handbook of Computable General Equilibrium Modeling, Elsevier, ed. 1, vol. 1, num. 1, 05.

D. Domeij, M. Floden. (2006). "Population aging and international capital flows", International Economic Review, 47, 1013-1032.

Deutsche Bank Research. (2006). China's pension system, Current Issues, China Special, February 17, 2006, Frankfurt.

Devereux, M. and K. Bilicka. (2012). CBT Corporate Tax Ranking 2012, Project Report. Centre for Business Taxation.

Diamond, P.A. (1965). "National Debt in a Neoclassical Growth Model", American Economic Review, 55, 1126-1150.

Fehr, H. (2000). "Pension Reform During the Demographic Transition", Scandinavian Journal of Economics, 102(3), 419-443.

Fehr, H., Jokisch, S., and Kotlikoff, L. J. (2004). "The Role of Immigration in Dealing with the Developed World's Demographic Transition”, Finanzarchiv, 60(3), 296-324.

Fehr, H., Jokisch, S., and Kotlikoff, L. J. (2005). 'The Developed World's Demographic Transition - The Roles of Capital Flows, Immigration, and Policy", in R. Brooks and A. Razin, eds., Social Security Reform, Cambridge, Cambridge University Press. 
Fehr, H., Jokisch, S., and Kotlikoff, L. J. (2007). "Will China Eat Our Lunch or Take Us to Dinner? Simulating the Transition Paths of the U.S., EU, Japan, and China”, in T. Ito and A.Rose (eds.), Fiscal Policy and Management, East Asia Seminar on Economics Volume 16, Chicago, University of Chicago Press.

Fehr, H., Jokisch, S. and L.J. Kotlikoff. (2008a). ”Dynamic Globalization and Its Potentially Alarming Prospects for Low-Wage Workers”, NBER Working Paper No. 14527, Cambridge.

Fehr, H., Jokisch, S., and Kotlikoff, L. J. (2008b). "Fertility, Mortality and the World's Demographic Transition”, Journal of Policy Modeling 30(3), 455-473.

Fehr, H, Sabine Jokisch and Laurence J. Kotlikoff. (2010). "Global Growth, Aging and Inequality Across and Within Generations", Oxford Review of Economic Policy 26 (4), 636-654.

Fehr, Hans, Sabine Jokisch, and Laurence J. Kotlikoff. (2013). "The world's interconnected demographic/fiscal transition", Journal of the Economics of Aging 1-2, 35-49.

Fehr, Hans, Sabine Jokisch, Manuel Kallweit, Fabian Kindermann, and Laurence J. Kotlikoff. (2013). Generational Policy and Aging in Closed and Open Dynamic General Equilibrium Models, chapter in Handbook of Computational General Equilibrium Modeling, Volume 1, 1719-1800, Elsevier.

Fehr, Hans, Sabine Jokisch, Ashwin Kambhampati and Laurence J. Kotlikoff. (2013). "Simulating the Elimination of the U,S. Corporate Income Tax", NBER Working paper No 19757, Cambridge.

Feldstein, M. S. (1974). "Social Security, Induced Retirement, and Aggregate Capital Accumulation”, Journal of Political Economy, 82(5), 905-926.

Jagadeesh Gokhale, John Sabelhaus, and Laurence J. Kotlikoff.(1996). "Understanding the Postwar Decline in United States Saving: A Cohort Analysis," The Brookings Papers on Economic Activity.

Hagist, C., and Kotlikoff, L. J. (2009). "Who's Going Broke? Comparing Healthcare Costs in ten OECD Countries", Hacienda PÃ ${ }^{\circ}$ blica Española, 188(1), 55-72.

Harberger, A. (1962). "The Incidence of the Corporation Income Tax", Journal of Political Economy 70, 215-240.

Jasmina Hasanhodzic and Laurence J. Kotlikoff. (2013). "Generational Risk - is it a Big Deal?: Simulating an 80-Period OLG Model with Aggregate Shocks", NBER Working Paper 
No 19179, Cambridge.

Hasanhodzic, Jasmina and Laurence J. Kotlikoff. (2014). Valuing Government Obligations When Markets Are Incomplete.

Hayashi, Fumio, Joseph Altonji, and Laurence Kotlikoff. (1996). "Risk-Sharing Between and Within Families," Econometrica 64(2), 261-294.

Ingenue. (2007). 'Ingenue 2: A Long Term Intertemporal World Model for the 21st Century", Mimeo.

International Labour Office (ILO). 2010. World Social Security Report 2010/11. Geneva.

International Monetary Fund Fiscal Affairs Department. 2010. From Stimulus to Consolidation: Revenue and Expenditure policies in Advanced and Emerging Economies, International Monetary Fund. Washington D.C.

International Monetary Fund. (2014). World Economic Outlook. Washington: International Monetary Fund, April.

International Monetary Fund. (2001) Government Finance Statistics: Manual. Washington, DC: International Monetary Fund.

Kato, R. R. (2002). "Government Deficit, Public Investment, and Public Capital in the Transition to an Aging Japan", Journal of the Japanese and International Economies, 16(4), 334-362.

Kennickell, A.B., Starr-McCluer, M. and B.J. Surette. (2000). "Recent Changes in U.S. Family Finances: Results from the 1998 Survey of Consumer Finances", Federal Reserve Bulletin 86, $1-29$.

Kotlikoff, Laurence H.(1981). Capital Taxation and Accumulation in a Life Cycle Growth Model. American Economic Review, September, pp. 533-44.

Kotlikoff, Laurence J., Smetters, Kent A. and Jan Walliser. (2007). ”Mitigating America's Demographic Dilemma by Pre-Funding Social Security", Journal of Monetary Economics 54, 247-266.

Lee, Ronald. 2014. "How Population Aging Affects the Macroeconomy." Panel on demographics, Federal Reserve Conference, Jackson Hole, August 22, 2014. http://www.kc.frb.org/publicat/sympos/2014

Mintz, J. and D. Chen. (2011). "New Estimates of Effective Corporate Tax Rates on Business Investment”, Tax and Budget Bulletin 64. Washington: Cato Institute. 
Nishiyama, S., and Smetters, K. (2005). "Consumption Taxes and Economic Efficiency with Idiosyncratic Wage Shocks", Journal of Political Economy, 113(5), 1088-1115.

OECD. 2006. Live Longer, Work Longer. Paris.

OECD. 2007a. Main Economic Indicators, December, Paris.

OECD. 2007b. OECD Health Data 2007: Statistics and Indicators for 30 Countries, Paris.

OECD. 2007c. Pensions at a Glance, Public Policies Across OECD Countries. Paris.

OECD. 2007d. Social Expenditure Database (SOCX 2007), 1980-2003, Paris.

OECD. 2008. Employment Outlook. Paris.

OECD. 2010a. Education At A Glance 2010. Paris.

OECD. 2010b. Revenue Statistics 1965-2009. Paris.

OECD. 2010c. Social Expenditure: Aggregated data, OECD Social Expenditure Statistics (database).

OECD. 2013. Pensions at a Glance, Public Policies Across OECD Countries. Paris.

Saarenheimo, T. (2005). "Ageing, Interest Rates, and Financial Flows", Discussion Paper 2/2005, Bank of Finland Research, Helsinki.

Seidman, Laurence. (1986). "A Phase-Down of Social Security: Transition in a Life Cycle Growth Model," National Tax Journal, March.

Social Security Association (SSA). (2006). Social Security Programs Throughout the World: The Americas, Washington D.C.

Social Security Association (SSA). (2007). Social Security Programs Throughout the World:Asia and the Pacific, Washington D.C.

Social Security Association (SSA). (2009). Social Security Programs Throughout the World: The Americas, Washington D.C.

Social Security Association (SSA). (2010). Social Security Programs Throughout the World: Asia and the Pacific, Washington D.C.

Statistics Bureau Japan. (2002). 1999 National Survey of Family Income and Expenditure, Vol. 7: Reference Material, No. 2: Family Assets. Tokyo 
Timmer, M., van Moergastel, T., Stuivenwold, E., Ypma, G., O’Mahony M., and Kangasniemi, M. (2007). "EU Klems Growth and Productivity Accounts", Groningen Growth and Development Centre and NIESR London. http://www.euklems.net/

Tobin, James. (1967). Life Cycle Saving and Balance Growth, in William Fellner, ed., Ten Economic Studies in the Tradition of Irving Fisher, 231-56. New York: Wiley.

United Nations Population Division (UNPD). (2014). "World Population Prospects: The 2012 Revision, Methodology of the United Nations Population Estimates and Projections". ESA/P/WP.235, New York.

U.S. Census Bureau. (2008). Current Population Survey, 2007 Annual Social and Economic Supplement, Washington D.C.

U.S. Department of Labor. (2007). "Consumer Expenditures in 2005”, U.S. Bureau of Labor Statistics Report998, Washington.

Wood, A. (1995). "How Trade Hurt Unskilled Workers", Journal of Economic Perspectives, 9(3), 57-80.

World Bank. (2005). South Asia Pension Schemes for the Formal Sector. Finance and Private Sector Development Unit. Washington.

World Bank. World Development Indicators Database. Washington, 2007, 2010, 2014. www.worldbank.org. 
Table 1: Comparing Actual and Simulated Population Projections

\begin{tabular}{|c|c|c|c|c|c|c|c|c|c|c|c|c|}
\hline \multirow{2}{*}{$\begin{array}{r}\text { Country } \\
\text { Year }\end{array}$} & \multicolumn{2}{|c|}{ U.S. } & \multicolumn{2}{|c|}{ EU } & \multicolumn{2}{|c|}{ Japan+ } & \multicolumn{2}{|c|}{ China } & \multicolumn{2}{|c|}{ India } & \multicolumn{2}{|c|}{ Russia } \\
\hline & 2013 & 2050 & 2013 & 2050 & 2013 & 2050 & 2013 & 2050 & 2013 & 2050 & 2013 & 2050 \\
\hline & \multicolumn{12}{|c|}{ Total Population (in millions) } \\
\hline Model & 319.4 & 402.6 & 510.4 & 500.2 & 176.8 & 154.4 & 1364.5 & 1401.5 & 1256.0 & 1623.9 & 141.9 & 134.1 \\
\hline \multirow[t]{2}{*}{ Official } & 319.9 & 400.9 & 509.2 & 511.6 & 176.3 & 159.4 & 1384.9 & 1385.0 & 1251.7 & 1620.1 & 142.7 & 131.1 \\
\hline & \multicolumn{12}{|c|}{ Fertility Rate } \\
\hline Model & 2.04 & 1.85 & 1.55 & 1.82 & 1.42 & 1.49 & 1.68 & 1.85 & 2.56 & 1.85 & 1.48 & 1.53 \\
\hline Official & 1.97 & 1.99 & 1.58 & 1.83 & 1.41 & 1.73 & 1.66 & 1.81 & 2.50 & 1.92 & 1.53 & 1.69 \\
\hline \multirow{2}{*}{\multicolumn{13}{|c|}{ Age Structure (percent of total population) }} \\
\hline & & & & & & & & & & & & \\
\hline Model & 13.61 & 11.76 & 9.89 & 10.03 & 9.42 & 7.34 & 12.50 & 10.76 & 20.43 & 12.06 & 11.99 & 9.28 \\
\hline $\begin{array}{r}\text { Official } \\
10-19\end{array}$ & 12.99 & 12.10 & 10.45 & 10.01 & 8.78 & 8.17 & 12.38 & 9.74 & 19.40 & 12.86 & 11.10 & 11.31 \\
\hline Model & 12.91 & 12.17 & 10.58 & 10.00 & 9.67 & 8.22 & 13.43 & 10.82 & 18.34 & 12.36 & 9.61 & 9.90 \\
\hline $\begin{array}{r}\text { Official } \\
20-29\end{array}$ & 13.39 & 12.19 & 10.50 & 9.94 & 10.09 & 8.52 & 12.49 & 10.00 & 19.10 & 13.52 & 9.99 & 11.34 \\
\hline Model & 13.80 & 12.33 & 12.13 & 10.84 & 11.43 & 8.83 & 15.60 & 10.84 & 16.51 & 12.74 & 14.11 & 9.76 \\
\hline $\begin{array}{r}\text { Official } \\
30-39\end{array}$ & 13.86 & 12.54 & 12.48 & 10.59 & 11.47 & 9.21 & 17.35 & 10.40 & 17.73 & 14.09 & 15.93 & 11.54 \\
\hline Model & 12.84 & 12.98 & 12.98 & 11.27 & 13.79 & 10.13 & 14.76 & 12.38 & 14.84 & 13.50 & 16.79 & 13.23 \\
\hline $\begin{array}{r}\text { Official } \\
40-49\end{array}$ & 13.07 & 12.42 & 13.79 & 11.43 & 13.83 & 9.87 & 14.73 & 12.46 & 14.86 & 14.31 & 15.44 & 13.65 \\
\hline Model & 12.98 & 12.51 & 15.28 & 11.58 & 14.68 & 11.28 & 17.27 & 11.66 & 11.86 & 14.15 & 13.86 & 12.68 \\
\hline $\begin{array}{r}\text { Official } \\
50-59\end{array}$ & 13.29 & 11.99 & 14.74 & 11.35 & 14.72 & 10.19 & 16.73 & 11.46 & 11.75 & 14.00 & 13.45 & 12.22 \\
\hline Model & 14.27 & 12.05 & 14.19 & 12.32 & 13.06 & 11.64 & 12.98 & 13.62 & 9.27 & 13.09 & 15.67 & 11.78 \\
\hline $\begin{array}{r}\text { Official } \\
60-69\end{array}$ & 13.62 & 11.76 & 13.67 & 11.55 & 13.09 & 11.86 & 12.40 & 13.13 & 8.79 & 12.91 & 15.07 & 11.47 \\
\hline Model & 11.05 & 11.90 & 12.25 & 13.04 & 12.73 & 13.93 & 9.41 & 14.92 & 6.19 & 12.45 & 12.37 & 18.49 \\
\hline $\begin{array}{r}\text { Official } \\
70-90\end{array}$ & 10.31 & 10.66 & 11.23 & 12.50 & 12.76 & 12.77 & 8.25 & 15.47 & 5.17 & 10.22 & 9.70 & 14.80 \\
\hline Model & 8.55 & 14.30 & 12.71 & 20.92 & 15.22 & 28.63 & 4.05 & 15.01 & 2.56 & 9.64 & 5.60 & 13.88 \\
\hline Official & 9.47 & 16.34 & 13.13 & 22.64 & 15.26 & 29.41 & 5.68 & 17.34 & 3.20 & 8.09 & 9.33 & 13.68 \\
\hline
\end{tabular}


Table 2: Simulated Population Totals, Fertility Rates, and Age Structures, 2050 and 2100

\begin{tabular}{|c|c|c|c|c|c|c|c|c|c|c|c|c|}
\hline \multirow{2}{*}{$\begin{array}{l}\text { Country } \\
\text { Year } \\
\end{array}$} & \multicolumn{2}{|c|}{ U.S. } & \multicolumn{2}{|c|}{ EU } & \multicolumn{2}{|c|}{ Japan+ } & \multicolumn{2}{|c|}{ China } & \multicolumn{2}{|c|}{ India } & \multicolumn{2}{|c|}{ Russia } \\
\hline & 2050 & 2100 & 2050 & 2100 & 2050 & 2100 & 2050 & 2100 & 2050 & 2100 & 2050 & 2100 \\
\hline & \multicolumn{12}{|c|}{ Total Population (in millions) } \\
\hline & 402.6 & 444.21 & 500.2 & 470.12 & 154.44 & 105.95 & 1401.5 & 1157.05 & 1623.9 & 1499.02 & 134.1 & 102.1 \\
\hline & \multicolumn{12}{|c|}{ Fertility Rate } \\
\hline & 1.85 & 1.77 & 1.82 & 1.79 & 1.49 & 1.92 & 1.85 & 2.04 & 1.85 & 2.15 & 1.53 & 1.79 \\
\hline & \multicolumn{12}{|c|}{ Age Structure (percent of total population) } \\
\hline $0-9$ & 11.76 & 10.55 & 10.03 & 10.83 & 7.34 & 10.12 & 10.76 & 12.34 & 12.06 & 12.80 & 9.28 & 10.45 \\
\hline $10-19$ & 12.17 & 10.94 & 10.00 & 11.01 & 8.22 & 10.18 & 10.82 & 12.30 & 12.36 & 12.40 & 9.90 & 10.65 \\
\hline $20-29$ & 12.33 & 11.58 & 10.84 & 11.82 & 8.83 & 10.44 & 10.84 & 12.13 & 12.74 & 12.10 & 9.76 & 11.24 \\
\hline $30-39$ & 12.98 & 12.12 & 11.27 & 12.17 & 10.13 & 10.55 & 12.38 & 12.06 & 13.50 & 12.06 & 13.23 & 12.04 \\
\hline $40-49$ & 12.51 & 12.41 & 11.58 & 12.27 & 11.28 & 10.58 & 11.66 & 12.03 & 14.15 & 12.05 & 13.68 & 12.66 \\
\hline $50-59$ & 12.05 & 12.67 & 12.32 & 12.19 & 11.64 & 11.18 & 13.62 & 12.71 & 13.09 & 12.30 & 11.78 & 14.66 \\
\hline $60-69$ & 11.90 & 12.73 & 13.04 & 11.99 & 13.93 & 12.42 & 14.92 & 12.81 & 12.45 & 13.01 & 18.49 & 15.32 \\
\hline $70-90$ & 14.30 & 16.99 & 20.92 & 17.73 & 28.63 & 24.52 & 15.01 & 13.62 & 9.64 & 13.28 & 13.88 & 12.98 \\
\hline
\end{tabular}

Table 3: Production Parameters

\begin{tabular}{lc|c}
\hline & Symbol & Value \\
\hline Capital share in production & $\alpha$ & 0.35 \\
Low-skilled labor share $(k=1)$ & $\beta_{l}$ & 0.40 \\
High-skilled labor share $(k=2)$ & $\beta_{h}$ & 0.25 \\
Technology coefficient & $\phi$ & 1.68 \\
Depreciation rate & $\delta_{K}$ & 0.075 \\
\hline
\end{tabular}


Table 4: Preference, Productivity and Policy Parameters in 2013

\begin{tabular}{lc|cccccc}
\hline & Symbol & U.S. & EU & Japan+ & China & India & Russia \\
Time preference rate (approximate) & $\delta$ & -.0243 & -.0440 & -.0333 & -.0560 & -.0043 & -.0086 \\
Intertemporal elasticity of substitution & $\gamma$ & 0.25 & 0.25 & 0.25 & 0.25 & 0.25 & 0.25 \\
Intratemporal elasticity of substitution & $\rho$ & 0.4 & 0.4 & 0.4 & 0.4 & 0.4 & 0.4 \\
Leisure preference parameter & $\varepsilon$ & 1.5 & 1.5 & 1.5 & 1.5 & 1.5 & 1.5 \\
Shift parameter for productivity & $\xi$ & 1.00 & .559 & .625 & .207 & .101 & .311 \\
Technical progress & $\lambda$ & 0.01 & 0.01 & 0.01 & 0.01 & 0.01 & 0.01 \\
Wage tax progressivity (in \%) & $\varphi$ & 0.3 & 0.3 & 0.3 & 0 & 0 & 0 \\
Age of retirement & $\bar{a}$ & 63 & 60 & 60 & 60 & 60 & 58 \\
Corporate Tax Rate (in \%) & $\tau^{c}$ & 40.0 & 22.8 & 35.2 & 25.0 & 34.0 & 20.0 \\
\hline
\end{tabular}


Table 5: The year 2013 of the baseline path

\begin{tabular}{|c|c|c|c|c|c|c|c|c|c|c|c|c|}
\hline & \multicolumn{6}{|c|}{ Model } & \multicolumn{6}{|c|}{ Actual } \\
\hline & U.S. & EU & Japan+ & China & India & Russia & U.S. & EU & Japan+ & China & India & Russia \\
\hline Gross Domestic Product (PPP) as a share of U.S. & 100.0 & 104.1 & 38.5 & 96.4 & 40.2 & 20.5 & 100.0 & 104.2 & 37.9 & 96.3 & 40.4 & 20.8 \\
\hline Private consumption as a share of GDP & 67.7 & 56.3 & 57.8 & 34.5 & 59.6 & 51.0 & 68.6 & 57.5 & 58.0 & 34.0 & 61.0 & 52.0 \\
\hline Government consumption as a share of GDP ${ }^{a}$ & 19.5 & 23.1 & 18.4 & 18.9 & 16.9 & 22.9 & & & & & & \\
\hline Fossil Fuel Rents as a Share of GDP & 0.9 & 0.3 & 0.1 & 2.7 & 2.5 & 17.2 & 1.0 & 0.3 & 0.0 & 3.4 & 2.9 & 17.1 \\
\hline \multicolumn{13}{|l|}{ Government Revenues as a percentage of $\mathrm{GDP}^{b}$} \\
\hline Total tax revenues & 27.8 & 28.1 & 28.6 & 21.8 & 20.6 & 17.4 & 21.0 & 22.7 & 26.2 & 20.9 & 17.5 & 18.2 \\
\hline Consumption tax & 11.6 & 14.5 & 10.3 & 16.0 & 13.0 & 10.7 & 9.8 & 11.7 & 13.7 & 15.7 & 11.7 & 11.3 \\
\hline Corporate tax & 4.7 & 4.2 & 5.6 & 3.4 & 4.7 & 3.5 & 2.4 & 2.7 & 5.5 & 4.1 & 3.7 & 3.1 \\
\hline Income Tax & 11.5 & 9.5 & 12.7 & 2.4 & 2.9 & 3.2 & 8.8 & 8.3 & 7.0 & 1.1 & 2.0 & 3.8 \\
\hline \multicolumn{13}{|l|}{ Non-tax revenues } \\
\hline Social insurance revenues & 5.7 & 15.9 & 5.7 & 1.7 & 2.0 & 7.3 & 5.7 & 15.8 & 0.5 & 1.5 & 1.9 & 7.2 \\
\hline Natural resources & 0.7 & 0.3 & 0.1 & 0.0 & 0.3 & 11.5 & 1.1 & 1.5 & 2.1 & 0.0 & 0.4 & 11.1 \\
\hline \multicolumn{13}{|l|}{ Total Government Expenditures } \\
\hline Health expenditures & 8.2 & 8.2 & 8.3 & 2.0 & 1.3 & 3.3 & 7.8 & 7.9 & 8.2 & 1.4 & 0.9 & 3.9 \\
\hline Education expenditures & 5.4 & 5.3 & 6.3 & 3.2 & 3.2 & 4.0 & 5.1 & 5.7 & 6.8 & 3.9 & 2.8 & 4.4 \\
\hline Government Purchases of G\&S excl. Health And Education & 5.9 & 9.7 & 3.8 & 13.7 & 12.4 & 15.6 & 6.3 & 9.6 & 4.0 & 13.8 & 12.8 & 16.0 \\
\hline Pension benefits & 8.8 & 17.0 & 6.0 & 2.8 & 4.6 & 9.2 & 8.5 & 16.9 & 6.2 & 2.6 & 4.1 & 8.9 \\
\hline Other transfer benefits & 5.4 & 5.9 & 8.3 & 1.8 & 1.4 & 3.4 & 5.1 & 6.5 & 8.5 & 2.4 & 1.7 & 3.9 \\
\hline Net Payments on Debt/Assets & 1.0 & -2.6 & 2.0 & 0.3 & 5.0 & 0.8 & 0.6 & -2.3 & 1.8 & 0.2 & 4.5 & 0.7 \\
\hline
\end{tabular}

a: Government consumption is here defined as the sum of education, health, and other purchases of goods and services. b:All following values are given as a percentage of GDP 
Table 6: Baseline Simulation Results - Capital and Labor Supplies are Relative to 2013 U.S.

\begin{tabular}{|c|c|c|c|c|c|c|c|c|c|}
\hline & Year & GDP & $\begin{array}{l}\text { Capital } \\
\text { Stock }\end{array}$ & $\begin{array}{c}\text { Labor Supply } \\
\text { Low-Skilled }\end{array}$ & $\begin{array}{l}\text { Labor Supply } \\
\text { High-Skilled }\end{array}$ & $\begin{array}{c}\text { Corporate } \\
\text { Tax }\end{array}$ & $\begin{array}{c}\text { Income } \\
\text { Tax }\end{array}$ & $\begin{array}{l}\text { Pension } \\
\text { Tax }\end{array}$ & $\begin{array}{c}\text { Consumption } \\
\text { Tax }\end{array}$ \\
\hline \multirow[t]{6}{*}{ U.S. } & 2013 & 1.00 & 1.00 & 1.00 & 1.00 & 40.00 & 13.13 & 8.89 & 18.46 \\
\hline & 2020 & 1.18 & 1.28 & 1.14 & 1.13 & 40.00 & 15.35 & 10.34 & 21.14 \\
\hline & 2040 & 1.66 & 1.72 & 1.65 & 1.64 & 40.00 & 18.56 & 12.57 & 26.40 \\
\hline & 2060 & 2.24 & 2.38 & 2.20 & 2.20 & 40.00 & 19.82 & 14.53 & 29.20 \\
\hline & 2080 & 3.01 & 3.42 & 2.84 & 2.86 & 40.00 & 20.96 & 15.23 & 32.60 \\
\hline & 2100 & 3.68 & 4.11 & 3.52 & 3.58 & 40.00 & 21.78 & 16.61 & 34.47 \\
\hline \multirow[t]{6}{*}{ E.U. } & 2013 & 1.04 & 1.20 & 0.95 & 1.02 & 22.80 & 12.87 & 24.62 & 24.41 \\
\hline & 2020 & 1.18 & 1.46 & 1.04 & 1.12 & 22.80 & 13.97 & 26.02 & 25.72 \\
\hline & 2040 & 1.65 & 1.96 & 1.48 & 1.60 & 22.80 & 16.18 & 28.77 & 28.54 \\
\hline & 2060 & 2.42 & 2.94 & 2.17 & 2.32 & 22.80 & 16.55 & 25.01 & 31.92 \\
\hline & 2080 & 3.13 & 4.04 & 2.66 & 2.98 & 22.80 & 16.91 & 30.74 & 32.27 \\
\hline & 2100 & 3.87 & 4.90 & 3.29 & 3.81 & 22.80 & 17.04 & 33.80 & 31.92 \\
\hline \multirow[t]{6}{*}{ Japan+ } & 2013 & 0.38 & 0.40 & 0.38 & 0.38 & 35.20 & 13.62 & 8.88 & 18.47 \\
\hline & 2020 & 0.41 & 0.47 & 0.39 & 0.39 & 35.20 & 14.38 & 9.65 & 18.46 \\
\hline & 2040 & 0.45 & 0.49 & 0.44 & 0.44 & 35.20 & 14.44 & 12.96 & 16.15 \\
\hline & 2060 & 0.53 & 0.58 & 0.51 & 0.50 & 35.20 & 14.87 & 12.68 & 15.95 \\
\hline & 2080 & 0.56 & 0.66 & 0.52 & 0.52 & 35.20 & 15.95 & 14.46 & 16.52 \\
\hline & 2100 & 0.62 & 0.72 & 0.58 & 0.58 & 35.20 & 16.59 & 14.67 & 17.35 \\
\hline \multirow[t]{6}{*}{ China } & 2013 & 0.96 & 1.07 & 0.97 & 0.77 & 25.00 & 1.74 & 2.62 & 48.15 \\
\hline & 2020 & 1.28 & 1.54 & 1.27 & 0.98 & 25.00 & 1.70 & 2.74 & 44.49 \\
\hline & 2040 & 2.89 & 3.38 & 3.06 & 2.19 & 25.00 & 1.87 & 2.42 & 42.93 \\
\hline & 2060 & 5.49 & 6.55 & 5.94 & 3.93 & 25.00 & 2.16 & 2.57 & 48.23 \\
\hline & 2080 & 7.75 & 9.85 & 8.27 & 5.22 & 25.00 & 2.26 & 4.60 & 46.28 \\
\hline & 2100 & 9.05 & 11.32 & 9.89 & 6.10 & 25.00 & 2.23 & 6.24 & 43.07 \\
\hline \multirow[t]{6}{*}{ India } & 2013 & 0.40 & 0.42 & 0.42 & 0.34 & 34.00 & 3.34 & 3.22 & 21.13 \\
\hline & 2020 & 0.61 & 0.70 & 0.63 & 0.49 & 34.00 & 3.18 & 3.06 & 21.54 \\
\hline & 2040 & 1.92 & 2.11 & 2.08 & 1.55 & 34.00 & 3.55 & 2.36 & 26.87 \\
\hline & 2060 & 4.12 & 4.61 & 4.50 & 3.20 & 34.00 & 4.31 & 3.39 & 34.63 \\
\hline & 2080 & 6.64 & 7.95 & 7.09 & 4.89 & 34.00 & 5.06 & 6.45 & 39.38 \\
\hline & 2100 & 9.62 & 11.30 & 10.52 & 7.07 & 34.00 & 5.35 & 7.61 & 41.96 \\
\hline \multirow[t]{6}{*}{ Rusia } & 2013 & 0.20 & 0.20 & 0.16 & 0.16 & 20.00 & 5.92 & 13.37 & 22.74 \\
\hline & 2020 & 0.23 & 0.24 & 0.17 & 0.17 & 20.00 & 7.30 & 14.95 & 27.96 \\
\hline & 2040 & 0.38 & 0.41 & 0.32 & 0.31 & 20.00 & 8.72 & 13.46 & 37.76 \\
\hline & 2060 & 0.61 & 0.71 & 0.54 & 0.50 & 20.00 & 10.04 & 11.71 & 47.74 \\
\hline & 2080 & 0.79 & 0.99 & 0.69 & 0.63 & 20.00 & 10.77 & 18.65 & 50.27 \\
\hline & 2100 & 0.87 & 1.12 & 0.80 & 0.73 & 20.00 & 12.45 & 23.14 & 58.13 \\
\hline
\end{tabular}


Table 7: Marginal Products and Factor Payments in the Baseline Transition

\begin{tabular}{|c|c|c|c|c|c|c|c|}
\hline \multirow[b]{2}{*}{ Country } & \multirow[b]{2}{*}{ Year } & \multirow{2}{*}{$\begin{array}{c}\text { Marg. Prod. } \\
\text { Capital }\end{array}$} & \multirow{2}{*}{$\begin{array}{c}\text { Global Int. } \\
\text { Rate }\end{array}$} & \multicolumn{2}{|c|}{ Marg. Prod. of Labor } & \multicolumn{2}{|c|}{ Wage Rates* } \\
\hline & & & & Low & High & Low & High \\
\hline \multirow[t]{6}{*}{ U.S. } & 2013 & 0.175 & 0.060 & 1.000 & 1.575 & 1.000 & 1.575 \\
\hline & 2020 & 0.162 & 0.052 & 1.041 & 1.645 & 1.041 & 1.645 \\
\hline & 2040 & 0.170 & 0.057 & 1.013 & 1.610 & 1.013 & 1.610 \\
\hline & 2060 & 0.167 & 0.055 & 1.027 & 1.618 & 1.027 & 1.618 \\
\hline & 2080 & 0.155 & 0.048 & 1.068 & 1.676 & 1.068 & 1.676 \\
\hline & 2100 & 0.159 & 0.050 & 1.060 & 1.643 & 1.060 & 1.643 \\
\hline \multirow[t]{6}{*}{ E.U. } & 2013 & 0.153 & 0.060 & 1.107 & 1.620 & 0.496 & 0.726 \\
\hline & 2020 & 0.143 & 0.052 & 1.150 & 1.678 & 0.577 & 0.842 \\
\hline & 2040 & 0.149 & 0.057 & 1.127 & 1.635 & 0.966 & 1.402 \\
\hline & 2060 & 0.146 & 0.055 & 1.131 & 1.665 & 1.131 & 1.665 \\
\hline & 2080 & 0.138 & 0.048 & 1.190 & 1.674 & 1.190 & 1.674 \\
\hline & 2100 & 0.140 & 0.050 & 1.192 & 1.624 & 1.192 & 1.624 \\
\hline \multirow[t]{6}{*}{ Japan+ } & 2013 & 0.168 & 0.060 & 1.033 & 1.589 & 0.549 & 0.844 \\
\hline & 2020 & 0.156 & 0.052 & 1.071 & 1.664 & 0.618 & 0.121 \\
\hline & 2040 & 0.163 & 0.057 & 1.038 & 1.641 & 0.913 & 1.443 \\
\hline & 2060 & 0.160 & 0.055 & 1.042 & 1.676 & 1.042 & 1.676 \\
\hline & 2080 & 0.149 & 0.048 & 1.084 & 1.729 & 1.084 & 1.729 \\
\hline & 2100 & 0.153 & 0.050 & 1.074 & 1.701 & 1.074 & 1.701 \\
\hline \multirow[t]{6}{*}{ China } & 2013 & 0.155 & 0.060 & 0.974 & 1.948 & 0.091 & 0.182 \\
\hline & 2020 & 0.145 & 0.052 & 1.004 & 2.046 & 0.153 & 0.312 \\
\hline & 2040 & 0.151 & 0.057 & 0.952 & 2.097 & 0.520 & 1.146 \\
\hline & 2060 & 0.148 & 0.055 & 0.933 & 2.221 & 0.878 & 2.090 \\
\hline & 2080 & 0.139 & 0.048 & 0.948 & 2.364 & 0.948 & 2.364 \\
\hline & 2100 & 0.142 & 0.050 & 0.929 & 2.373 & 0.929 & 2.373 \\
\hline \multirow[t]{6}{*}{ India } & 2013 & 0.166 & 0.060 & 0.943 & 1.866 & 0.048 & 0.096 \\
\hline & 2020 & 0.154 & 0.052 & 0.976 & 1.958 & 0.077 & 0.155 \\
\hline & 2040 & 0.161 & 0.057 & 0.933 & 1.974 & 0.249 & 0.528 \\
\hline & 2060 & 0.158 & 0.055 & 0.925 & 2.055 & 0.421 & 0.935 \\
\hline & 2080 & 0.148 & 0.048 & 0.948 & 2.168 & 0.610 & 1.394 \\
\hline & 2100 & 0.151 & 0.050 & 0.929 & 2.176 & 0.772 & 1.808 \\
\hline \multirow[t]{6}{*}{ Rusia } & 2013 & 0.150 & 0.060 & 1.092 & 1.699 & 0.232 & 0.360 \\
\hline & 2020 & 0.140 & 0.052 & 1.128 & 1.771 & 0.297 & 0.467 \\
\hline & 2040 & 0.146 & 0.057 & 1.089 & 1.768 & 0.660 & 1.072 \\
\hline & 2060 & 0.144 & 0.055 & 1.086 & 1.822 & 1.030 & 1.728 \\
\hline & 2080 & 0.135 & 0.048 & 1.113 & 1.906 & 1.113 & 1.906 \\
\hline & 2100 & 0.138 & 0.050 & 1.099 & 1.890 & 1.099 & 1.891 \\
\hline
\end{tabular}

*Measured at age 30 per unit of effective time scaled by the wage of 30 year-old low skilled Americans in 2013. Marginal product of labor is in proportion to U.S. 2013 levels.

The wedge between the marginal product of capital and the global interest rate is a function of both the depreciation rate ( 7.5 percent) and country specific corporate tax rates. 
Table 8: Total Average and Total Average Marginal Wage Tax Rate in the Baseline

\begin{tabular}{|c|c|c|c|c|}
\hline \multirow[b]{2}{*}{ Country } & \multirow[b]{2}{*}{ Year } & \multirow{2}{*}{$\begin{array}{c}\text { Average Tax Rate } \\
\text { All }\end{array}$} & \multicolumn{2}{|c|}{ Average Marginal Tax Rate* } \\
\hline & & & Low-Skill & High-Skill \\
\hline \multirow[t]{6}{*}{ U.S. } & 2013 & 37.602 & 49.012 & 49.712 \\
\hline & 2020 & 43.140 & 53.824 & 53.924 \\
\hline & 2040 & 52.015 & 62.286 & 60.686 \\
\hline & 2060 & 56.944 & 67.301 & 64.101 \\
\hline & 2080 & 60.776 & 71.785 & 68.585 \\
\hline & 2100 & 64.020 & 75.151 & 70.651 \\
\hline \multirow[t]{6}{*}{ E.U. } & 2013 & 57.104 & 63.914 & 45.914 \\
\hline & 2020 & 60.447 & 67.146 & 48.346 \\
\hline & 2040 & 67.150 & 75.379 & 56.179 \\
\hline & 2060 & 65.748 & 76.985 & 63.985 \\
\hline & 2080 & 72.043 & 84.214 & 66.414 \\
\hline & 2100 & 75.040 & 86.985 & 65.885 \\
\hline \multirow[t]{6}{*}{ Japan+ } & 2013 & 38.097 & 45.812 & 44.612 \\
\hline & 2020 & 39.617 & 47.412 & 45.912 \\
\hline & 2040 & 41.305 & 49.241 & 45.641 \\
\hline & 2060 & 41.309 & 50.993 & 49.493 \\
\hline & 2080 & 44.593 & 54.863 & 52.163 \\
\hline & 2100 & 46.038 & 56.421 & 53.521 \\
\hline \multirow[t]{6}{*}{ China } & 2013 & 36.860 & 36.778 & 34.178 \\
\hline & 2020 & 35.228 & 35.196 & 32.496 \\
\hline & 2040 & 34.326 & 34.321 & 31.921 \\
\hline & 2060 & 37.271 & 37.324 & 34.724 \\
\hline & 2080 & 38.497 & 38.547 & 33.947 \\
\hline & 2100 & 38.576 & 38.519 & 32.319 \\
\hline \multirow[t]{6}{*}{ India } & 2013 & 23.997 & 23.924 & 20.724 \\
\hline & 2020 & 23.964 & 23.995 & 20.895 \\
\hline & 2040 & 27.086 & 27.098 & 24.698 \\
\hline & 2060 & 33.422 & 33.406 & 30.006 \\
\hline & 2080 & 39.759 & 39.764 & 33.364 \\
\hline & 2100 & 42.523 & 42.477 & 34.877 \\
\hline \multirow[t]{6}{*}{ Rusia } & 2013 & 37.815 & 37.815 & 37.815 \\
\hline & 2020 & 44.099 & 44.099 & 44.099 \\
\hline & 2040 & 49.587 & 49.587 & 49.587 \\
\hline & 2060 & 54.060 & 54.060 & 54.060 \\
\hline & 2080 & 62.873 & 62.873 & 62.873 \\
\hline & 2100 & 72.351 & 72.351 & 72.351 \\
\hline
\end{tabular}

*Average marginal tax rates are the average marginal tax faced by each cohort of a skill group in a given year. The high skilled face no marginal social security tax, so as this share of taxes becomes larger, they will face relatively smaller marginal tax rates. Sum of income, pension, and consumption tax rates, where the consumption tax is converted to an income equivalent. 
Table 9: GDP in Different Scenarios as a Share of 2013 Baseline U.S. GDP

\begin{tabular}{|c|c|c|c|c|c|c|c|c|}
\hline & Year & $\begin{array}{l}\text { Baseline } \\
\text { GDP }\end{array}$ & $\begin{array}{l}\text { Price } \\
\text { Shock }\end{array}$ & $\begin{array}{l}\text { Price Shock \& } \\
\text { Debt Finance }\end{array}$ & $\begin{array}{l}\text { Corp. Tax } \\
\text { Reform }\end{array}$ & $\begin{array}{l}\text { Pension } \\
\text { Reform }\end{array}$ & $\begin{array}{l}\text { Fertility } \\
\text { Increase }\end{array}$ & $\begin{array}{c}\text { Combined } \\
\text { Scenario }\end{array}$ \\
\hline \multirow[t]{6}{*}{ U.S. } & 2013 & 1.000 & 1.014 & 1.015 & 0.997 & 0.998 & 1.000 & 1.009 \\
\hline & 2020 & 1.181 & 1.191 & 1.190 & 1.179 & 1.183 & 1.181 & 1.190 \\
\hline & 2040 & 1.662 & 1.667 & 1.661 & 1.661 & 1.677 & 1.661 & 1.677 \\
\hline & 2060 & 2.242 & 2.242 & 2.234 & 2.241 & 2.267 & 2.238 & 2.261 \\
\hline & 2080 & 3.007 & 3.002 & 2.993 & 3.006 & 3.042 & 3.006 & 3.032 \\
\hline & 2100 & 3.680 & 3.680 & 3.670 & 3.679 & 3.727 & 3.689 & 3.732 \\
\hline \multirow[t]{6}{*}{ E.U. } & 2013 & 1.038 & 1.051 & 1.052 & 1.035 & 1.036 & 1.037 & 1.047 \\
\hline & 2020 & 1.179 & 1.189 & 1.187 & 1.177 & 1.181 & 1.179 & 1.189 \\
\hline & 2040 & 1.645 & 1.650 & 1.646 & 1.644 & 1.658 & 1.644 & 1.659 \\
\hline & 2060 & 2.422 & 2.424 & 2.416 & 2.421 & 2.448 & 2.419 & 2.443 \\
\hline & 2080 & 3.130 & 3.127 & 3.117 & 3.129 & 3.169 & 3.128 & 3.161 \\
\hline & 2100 & 3.873 & 3.872 & 3.861 & 3.872 & 3.925 & 3.883 & 3.929 \\
\hline \multirow[t]{6}{*}{ Japan+ } & 2013 & 0.383 & 0.389 & 0.389 & 0.381 & 0.382 & 0.382 & 0.387 \\
\hline & 2020 & 0.410 & 0.414 & 0.414 & 0.409 & 0.411 & 0.410 & 0.415 \\
\hline & 2040 & 0.453 & 0.455 & 0.453 & 0.452 & 0.458 & 0.452 & 0.458 \\
\hline & 2060 & 0.526 & 0.526 & 0.524 & 0.525 & 0.534 & 0.525 & 0.533 \\
\hline & 2080 & 0.559 & 0.559 & 0.556 & 0.559 & 0.569 & 0.559 & 0.568 \\
\hline & 2100 & 0.616 & 0.615 & 0.613 & 0.616 & 0.627 & 0.618 & 0.628 \\
\hline \multirow[t]{6}{*}{ China } & 2013 & 0.959 & 0.959 & 0.959 & 0.957 & 0.959 & 0.959 & 0.956 \\
\hline & 2020 & 1.281 & 1.279 & 1.278 & 1.279 & 1.284 & 1.281 & 1.280 \\
\hline & 2040 & 2.892 & 2.891 & 2.882 & 2.890 & 2.917 & 2.890 & 2.909 \\
\hline & 2060 & 5.485 & 5.479 & 5.458 & 5.483 & 5.560 & 5.478 & 5.537 \\
\hline & 2080 & 7.746 & 7.727 & 7.695 & 7.744 & 7.877 & 7.744 & 7.842 \\
\hline & 2100 & 9.053 & 9.043 & 9.007 & 9.051 & 9.233 & 9.083 & 9.237 \\
\hline \multirow[t]{6}{*}{ India } & 2013 & 0.401 & 0.401 & 0.401 & 0.400 & 0.400 & 0.401 & 0.399 \\
\hline & 2020 & 0.614 & 0.614 & 0.614 & 0.613 & 0.614 & 0.614 & 0.614 \\
\hline & 2040 & 1.923 & 1.925 & 1.920 & 1.921 & 1.935 & 1.921 & 1.934 \\
\hline & 2060 & 4.118 & 4.117 & 4.104 & 4.116 & 4.159 & 4.113 & 4.148 \\
\hline & 2080 & 6.636 & 6.626 & 6.607 & 6.635 & 6.711 & 6.633 & 6.689 \\
\hline & 2100 & 9.623 & 9.616 & 9.591 & 9.622 & 9.746 & 9.643 & 9.747 \\
\hline \multirow[t]{6}{*}{ Rusia } & 2013 & 0.204 & 0.192 & 0.191 & 0.215 & 0.211 & 0.205 & 0.211 \\
\hline & 2020 & 0.227 & 0.215 & 0.214 & 0.238 & 0.235 & 0.229 & 0.235 \\
\hline & 2040 & 0.376 & 0.365 & 0.365 & 0.393 & 0.382 & 0.398 & 0.412 \\
\hline & 2060 & 0.611 & 0.602 & 0.610 & 0.638 & 0.604 & 0.717 & 0.735 \\
\hline & 2080 & 0.792 & 0.781 & 0.796 & 0.825 & 0.769 & 1.035 & 1.045 \\
\hline & 2100 & 0.871 & 0.876 & 0.895 & 0.910 & 0.814 & 1.209 & 1.216 \\
\hline
\end{tabular}


Table 10: Total Effective Wage Tax Rates in Different Scenarios

\begin{tabular}{|c|c|c|c|c|c|c|c|c|}
\hline & Year & Baseline & $\begin{array}{l}\text { Price } \\
\text { Shock }\end{array}$ & $\begin{array}{l}\text { Price Shock \& } \\
\text { Debt Finance }\end{array}$ & $\begin{array}{l}\text { Corp. Tax } \\
\text { Reform }\end{array}$ & $\begin{array}{l}\text { Pension } \\
\text { Reform }\end{array}$ & $\begin{array}{l}\text { Fertility } \\
\text { Increase }\end{array}$ & $\begin{array}{c}\text { Combined } \\
\text { Scenario }\end{array}$ \\
\hline \multirow[t]{6}{*}{ U.S. } & 2013 & 37.60 & 37.88 & 37.88 & 37.65 & 37.61 & 37.60 & 37.94 \\
\hline & 2020 & 43.14 & 43.36 & 43.38 & 43.18 & 43.11 & 43.13 & 43.37 \\
\hline & 2040 & 52.02 & 52.26 & 52.34 & 52.04 & 51.81 & 52.04 & 52.10 \\
\hline & 2060 & 56.94 & 57.26 & 57.35 & 56.95 & 56.62 & 57.00 & 57.01 \\
\hline & 2080 & 60.78 & 61.09 & 61.16 & 60.78 & 60.43 & 60.79 & 60.79 \\
\hline & 2100 & 64.02 & 64.08 & 64.15 & 64.03 & 63.58 & 63.91 & 63.57 \\
\hline \multirow[t]{6}{*}{ E.U. } & 2013 & 57.10 & 56.96 & 56.94 & 57.17 & 57.16 & 57.11 & 57.08 \\
\hline & 2020 & 60.45 & 60.34 & 60.35 & 60.50 & 60.44 & 60.44 & 60.38 \\
\hline & 2040 & 67.15 & 67.15 & 67.23 & 67.17 & 66.96 & 67.16 & 67.00 \\
\hline & 2060 & 65.75 & 65.92 & 65.98 & 65.74 & 65.54 & 65.78 & 65.75 \\
\hline & 2080 & 72.04 & 72.20 & 72.27 & 72.03 & 71.73 & 72.06 & 71.92 \\
\hline & 2100 & 75.04 & 75.13 & 75.19 & 75.03 & 74.69 & 74.94 & 74.70 \\
\hline \multirow[t]{6}{*}{ Japan+ } & 2013 & 38.10 & 37.93 & 37.94 & 38.14 & 38.08 & 38.10 & 37.96 \\
\hline & 2020 & 39.62 & 39.52 & 39.55 & 39.64 & 39.55 & 39.62 & 39.48 \\
\hline & 2040 & 41.31 & 41.27 & 41.33 & 41.32 & 41.10 & 41.33 & 41.12 \\
\hline & 2060 & 41.31 & 41.37 & 41.42 & 41.31 & 41.09 & 41.33 & 41.18 \\
\hline & 2080 & 44.59 & 44.66 & 44.69 & 44.59 & 44.42 & 44.57 & 44.47 \\
\hline & 2100 & 46.04 & 46.04 & 46.06 & 46.04 & 45.87 & 45.95 & 45.80 \\
\hline \multirow[t]{6}{*}{ China } & 2013 & 36.86 & 36.74 & 36.73 & 36.89 & 36.93 & 36.85 & 36.82 \\
\hline & 2020 & 35.23 & 35.15 & 35.15 & 35.25 & 35.26 & 35.22 & 35.20 \\
\hline & 2040 & 34.33 & 34.31 & 34.32 & 34.33 & 34.31 & 34.33 & 34.32 \\
\hline & 2060 & 37.27 & 37.29 & 37.29 & 37.27 & 37.28 & 37.27 & 37.30 \\
\hline & 2080 & 38.50 & 38.52 & 38.51 & 38.49 & 38.53 & 38.48 & 38.53 \\
\hline & 2100 & 38.58 & 38.58 & 38.57 & 38.57 & 38.59 & 38.54 & 38.56 \\
\hline \multirow[t]{6}{*}{ India } & 2013 & 24.00 & 23.76 & 23.80 & 24.07 & 23.93 & 23.99 & 23.77 \\
\hline & 2020 & 23.96 & 23.76 & 23.84 & 24.02 & 23.81 & 23.96 & 23.67 \\
\hline & 2040 & 27.09 & 26.99 & 27.11 & 27.12 & 26.75 & 27.13 & 26.76 \\
\hline & 2060 & 33.42 & 33.42 & 33.53 & 33.44 & 33.05 & 33.46 & 33.15 \\
\hline & 2080 & 39.76 & 39.82 & 39.90 & 39.77 & 39.41 & 39.75 & 39.50 \\
\hline & 2100 & 42.52 & 42.55 & 42.62 & 42.54 & 42.14 & 42.42 & 42.10 \\
\hline \multirow[t]{6}{*}{ Rusia } & 2013 & 37.82 & 45.59 & 37.48 & 40.21 & 37.94 & 37.84 & 48.68 \\
\hline & 2020 & 44.10 & 50.81 & 38.91 & 45.62 & 41.81 & 44.29 & 50.90 \\
\hline & 2040 & 49.59 & 53.82 & 57.21 & 51.06 & 34.99 & 48.58 & 41.71 \\
\hline & 2060 & 54.06 & 56.82 & 60.50 & 55.61 & 36.89 & 47.97 & 39.43 \\
\hline & 2080 & 62.87 & 65.00 & 69.28 & 63.91 & 36.06 & 47.71 & 33.51 \\
\hline & 2100 & 72.35 & 72.70 & 77.47 & 72.87 & 38.36 & 50.16 & 30.92 \\
\hline
\end{tabular}


Table 11: Average Wages in terms of 2013 U.S. Average Wage in Each Scenario

\begin{tabular}{|c|c|c|c|c|c|c|c|}
\hline & Year & $\begin{array}{l}\text { Price } \\
\text { Shock }\end{array}$ & $\begin{array}{c}\text { Price Shock \& } \\
\text { Debt Finance }\end{array}$ & $\begin{array}{l}\text { Corp. Tax } \\
\text { Reform }\end{array}$ & $\begin{array}{l}\text { Pension } \\
\text { Reform }\end{array}$ & $\begin{array}{l}\text { Fertility } \\
\text { Increase }\end{array}$ & $\begin{array}{c}\text { Combined } \\
\text { Scenario }\end{array}$ \\
\hline \multirow[t]{6}{*}{ U.S. } & 2013 & 1.000 & 1.000 & 1.000 & 1.000 & 1.000 & 1.000 \\
\hline & 2020 & 1.038 & 1.036 & 1.044 & 1.046 & 1.043 & 1.042 \\
\hline & 2040 & 1.006 & 1.003 & 1.018 & 1.027 & 1.015 & 1.017 \\
\hline & 2060 & 1.013 & 1.009 & 1.030 & 1.042 & 1.026 & 1.028 \\
\hline & 2080 & 1.050 & 1.046 & 1.069 & 1.083 & 1.066 & 1.068 \\
\hline & 2100 & 1.037 & 1.033 & 1.056 & 1.072 & 1.056 & 1.060 \\
\hline \multirow[t]{6}{*}{ E.U. } & 2013 & 0.481 & 0.481 & 0.482 & 0.482 & 0.482 & 0.481 \\
\hline & 2020 & 0.557 & 0.556 & 0.560 & 0.561 & 0.560 & 0.559 \\
\hline & 2040 & 0.926 & 0.923 & 0.938 & 0.944 & 0.935 & 0.935 \\
\hline & 2060 & 1.086 & 1.083 & 1.104 & 1.115 & 1.100 & 1.100 \\
\hline & 2080 & 1.121 & 1.117 & 1.142 & 1.154 & 1.139 & 1.138 \\
\hline & 2100 & 1.109 & 1.106 & 1.130 & 1.144 & 1.130 & 1.131 \\
\hline \multirow[t]{6}{*}{ Japan+ } & 2013 & 0.543 & 0.543 & 0.544 & 0.544 & 0.544 & 0.543 \\
\hline & 2020 & 0.611 & 0.610 & 0.615 & 0.616 & 0.614 & 0.614 \\
\hline & 2040 & 0.905 & 0.901 & 0.916 & 0.923 & 0.913 & 0.914 \\
\hline & 2060 & 1.037 & 1.033 & 1.054 & 1.065 & 1.050 & 1.051 \\
\hline & 2080 & 1.073 & 1.069 & 1.092 & 1.106 & 1.089 & 1.090 \\
\hline & 2100 & 1.060 & 1.056 & 1.080 & 1.095 & 1.080 & 1.082 \\
\hline \multirow[t]{6}{*}{ China } & 2013 & 0.097 & 0.097 & 0.097 & 0.097 & 0.097 & 0.097 \\
\hline & 2020 & 0.163 & 0.163 & 0.164 & 0.165 & 0.164 & 0.164 \\
\hline & 2040 & 0.571 & 0.569 & 0.578 & 0.583 & 0.577 & 0.577 \\
\hline & 2060 & 0.993 & 0.990 & 1.010 & 1.020 & 1.006 & 1.006 \\
\hline & 2080 & 1.093 & 1.090 & 1.113 & 1.126 & 1.110 & 1.110 \\
\hline & 2100 & 1.083 & 1.080 & 1.103 & 1.117 & 1.103 & 1.104 \\
\hline \multirow[t]{6}{*}{ India } & 2013 & 0.051 & 0.051 & 0.051 & 0.051 & 0.051 & 0.051 \\
\hline & 2020 & 0.082 & 0.082 & 0.083 & 0.083 & 0.083 & 0.083 \\
\hline & 2040 & 0.269 & 0.268 & 0.273 & 0.275 & 0.272 & 0.272 \\
\hline & 2060 & 0.462 & 0.461 & 0.470 & 0.475 & 0.468 & 0.469 \\
\hline & 2080 & 0.677 & 0.674 & 0.689 & 0.698 & 0.687 & 0.688 \\
\hline & 2100 & 0.865 & 0.863 & 0.881 & 0.894 & 0.881 & 0.884 \\
\hline \multirow[t]{6}{*}{ Rusia } & 2013 & 0.230 & 0.230 & 0.244 & 0.231 & 0.231 & 0.243 \\
\hline & 2020 & 0.295 & 0.295 & 0.313 & 0.298 & 0.297 & 0.312 \\
\hline & 2040 & 0.661 & 0.659 & 0.708 & 0.674 & 0.668 & 0.705 \\
\hline & 2060 & 1.042 & 1.039 & 1.119 & 1.070 & 1.056 & 1.113 \\
\hline & 2080 & 1.134 & 1.130 & 1.215 & 1.168 & 1.152 & 1.210 \\
\hline & 2100 & 1.122 & 1.119 & 1.204 & 1.158 & 1.143 & 1.204 \\
\hline
\end{tabular}


Table 12: Share of World Assets Owned by Citizens of Each Region in the Baseline Scenario

\begin{tabular}{c|cccccc}
\hline Year & U.S. & EU & Japan+ & China & India & Russia \\
\hline 2013 & 0.39 & 0.28 & 0.14 & 0.11 & 0.04 & 0.04 \\
2020 & 0.33 & 0.25 & 0.14 & 0.22 & 0.03 & 0.04 \\
2040 & 0.17 & 0.16 & 0.12 & 0.46 & 0.05 & 0.03 \\
2060 & 0.09 & 0.12 & 0.09 & 0.57 & 0.11 & 0.03 \\
2080 & 0.06 & 0.10 & 0.07 & 0.61 & 0.13 & 0.03 \\
2100 & 0.05 & 0.09 & 0.05 & 0.64 & 0.15 & 0.02 \\
\hline
\end{tabular}

Table 13: Russian Welfare* in Different Scenarios Relative to Baseline

\begin{tabular}{|c|c|c|c|c|c|c|c|c|c|c|c|c|}
\hline \multirow[b]{2}{*}{ Birth Year } & \multicolumn{2}{|c|}{ Price Shock } & \multicolumn{2}{|c|}{ Debt Finance } & \multicolumn{2}{|c|}{ Corporate Tax } & \multicolumn{2}{|c|}{ Pension } & \multicolumn{2}{|c|}{ Fertility } & \multicolumn{2}{|c|}{ Combined } \\
\hline & Low & High & Low & High & Low & High & Low & High & Low & High & Low & High \\
\hline 1930 & -4.0 & -3.7 & 0.7 & 0.7 & -1.4 & -1.3 & -0.5 & -0.5 & -0.1 & -0.1 & -6.8 & -6.4 \\
\hline 1935 & -4.7 & -4.4 & 0.4 & 0.4 & -1.6 & -1.5 & -0.6 & -0.5 & -0.3 & -0.3 & -7.7 & -7.2 \\
\hline 1940 & -5.1 & -4.7 & -1.0 & -0.9 & -1.7 & -1.6 & -0.5 & -0.5 & -0.4 & -0.4 & -8.2 & -7.7 \\
\hline 1945 & -5.3 & -4.9 & -1.9 & -1.7 & -1.8 & -1.7 & -0.4 & -0.3 & -0.6 & -0.6 & -8.5 & -8.0 \\
\hline 1950 & -5.4 & -5.0 & -2.5 & -2.3 & -1.9 & -1.8 & -0.2 & -0.2 & -0.6 & -0.6 & -8.5 & -7.9 \\
\hline 1955 & -6.0 & -5.6 & -3.5 & -3.3 & -3.7 & -3.7 & -3.0 & -3.2 & -0.7 & -0.7 & -13.6 & -13.4 \\
\hline 1960 & -5.2 & -4.8 & -2.9 & -2.6 & -1.9 & -1.7 & -7.1 & -7.5 & -0.6 & -0.5 & -14.7 & -14.5 \\
\hline 1965 & -4.7 & -4.3 & -2.1 & -1.9 & -0.9 & -0.7 & -9.0 & -9.4 & -0.4 & -0.4 & -14.9 & -14.7 \\
\hline 1970 & -4.5 & -4.2 & -1.7 & -1.5 & -0.2 & -0.1 & -9.6 & -9.9 & -0.4 & -0.4 & -14.7 & -14.4 \\
\hline 1975 & -4.6 & -4.3 & -1.6 & -1.5 & 0.2 & 0.3 & -9.3 & -9.5 & -0.6 & -0.6 & -14.3 & -14.0 \\
\hline 1980 & -4.6 & -4.3 & -1.8 & -1.7 & 0.5 & 0.6 & -6.2 & -6.4 & -1.5 & -1.4 & -11.8 & -11.4 \\
\hline 1990 & -4.7 & -4.5 & -2.8 & -2.7 & 1.3 & 1.4 & -1.4 & -1.6 & -5.5 & -5.0 & -10.3 & -9.7 \\
\hline 1995 & -4.5 & -4.2 & -3.9 & -3.7 & 1.6 & 1.6 & 1.0 & 0.7 & -6.0 & -5.4 & -8.1 & -7.5 \\
\hline 2000 & -3.9 & -3.6 & -5.2 & -4.8 & 1.6 & 1.6 & 3.2 & 2.7 & -5.0 & -4.4 & -4.5 & -4.1 \\
\hline 2010 & -3.0 & -2.7 & -5.8 & -5.2 & 1.5 & 1.5 & 6.1 & 5.3 & -3.9 & -3.3 & -0.1 & 0.1 \\
\hline 2020 & -2.4 & -2.2 & -5.5 & -4.9 & 1.5 & 1.4 & 8.0 & 7.0 & -0.9 & -0.6 & 4.5 & 4.2 \\
\hline 2030 & -1.9 & -1.7 & -5.3 & -4.8 & 1.4 & 1.3 & 9.8 & 8.5 & 0.4 & 0.6 & 6.8 & 6.2 \\
\hline 2050 & -1.1 & -1.0 & -5.1 & -4.7 & 1.6 & 1.5 & 17.6 & 15.1 & 9.7 & 8.5 & 20.9 & 18.0 \\
\hline 2100 & -0.2 & -0.2 & -5.2 & -4.8 & 2.2 & 2.1 & 26.2 & 23.6 & 17.5 & 16.4 & 35.2 & 31.7 \\
\hline
\end{tabular}

*Welfare for a skill- and country-specific cohort born in year $\mathrm{t}$ is measured as a compensating differential. The compensating differential measures the percentage change in annual consumption under the baseline simulation needed to achieve the same utility gain or losses as arises in the transition under consideration. 